Prepared in cooperation with the U.S. Army Corps of Engineers

Water-Quality Requirements, Tolerances, and Preferences of Pallid Sturgeon (Scaphirhynchus albus) in the Lower Missouri River

Scientific Investigations Report 2011-5186 
Front cover. Missouri River at sunset, photograph courtesy of Vicki Richmond, Missouri River Relief.

Back cover. Missouri River in central Missouri, photograph courtesy of Caanan Cowles, Missouri River Relief. 


\section{Water-Quality Requirements, Tolerances, and Preferences of Pallid Sturgeon (Scaphirhynchus albus) in the Lower Missouri River}

By Dale W. Blevins

Prepared in cooperation with the U.S. Army Corps of Engineers

Scientific Investigations Report 2011-5186 


\section{U.S. Department of the Interior \\ KEN SALAZAR, Secretary \\ U.S. Geological Survey \\ Marcia K. McNutt, Director}

U.S. Geological Survey, Reston, Virginia: 2011

For more information on the USGS — the Federal source for science about the Earth, its natural and living resources, natural hazards, and the environment, visit http://www.usgs.gov or call 1-888-ASK-USGS.

For an overview of USGS information products, including maps, imagery, and publications, visit http://www.usgs.gov/pubprod

Any use of trade, product, or firm names is for descriptive purposes only and does not imply endorsement by the U.S. Government.

Although this report is in the public domain, permission must be secured from the individual copyright owners to reproduce any copyrighted materials contained within this report.

Suggested citation:

Blevins, D.W., 2011, Water-quality requirements, tolerances, and preferences of pallid sturgeon (Scaphirhynchus albus) in the lower Missouri River: U.S. Geological Survey Scientific Investigations Report 2011-5186, 20 p. 


\section{Contents}

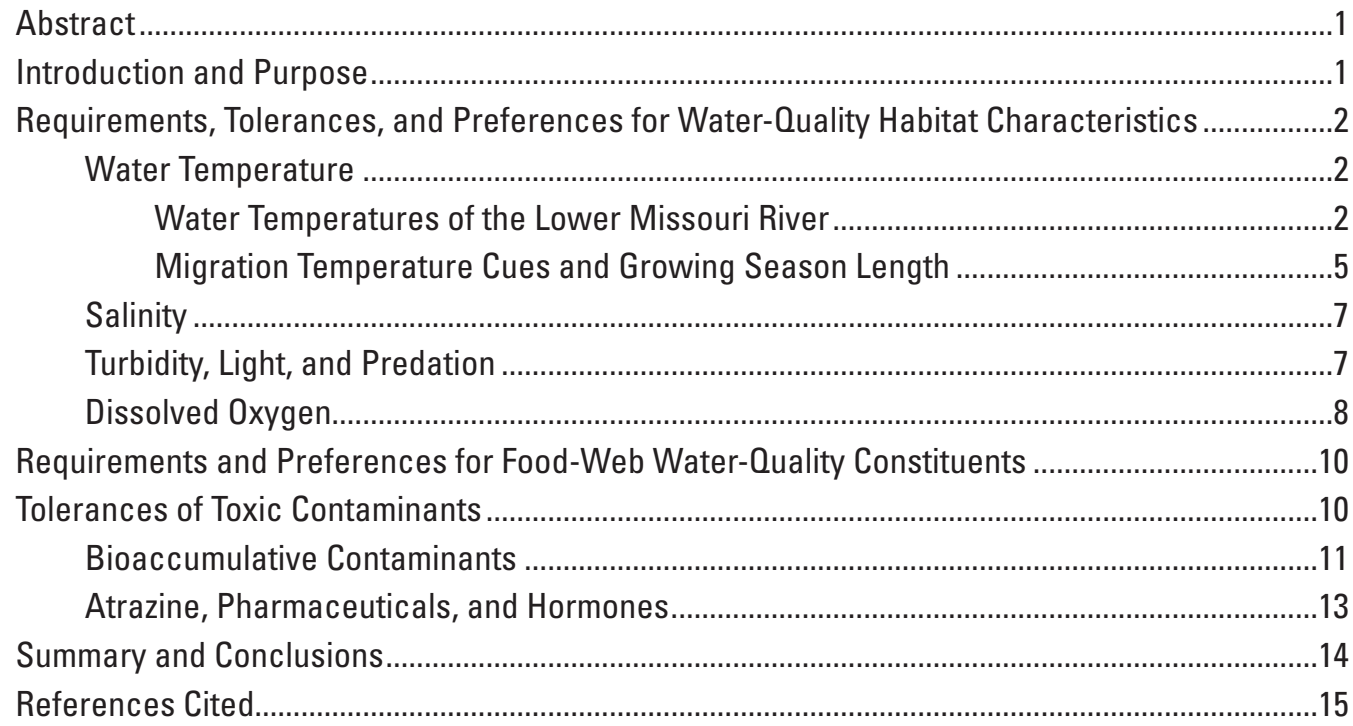

\section{Figures}

1. Maps showing location of Missouri River Basin, and location of streamflowgaging stations along the lower Missouri River downstream from

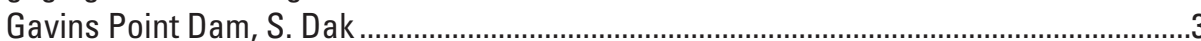

2. Graphs showing typical dissolved-oxygen crashes during rises and turbidity peaks on the lower Missouri River

\section{Tables}

1. Mean, maximum, and minimum water temperatures during July and August at seven streamflow-gaging stations on the lower Missouri River from 2006 through 2009

2. First day, last day, and length of growing season of pallid sturgeon at stations on the lower Missouri River from 2006 through 2009.

3. Median, maximum, and 75th percentile of mean-monthly atrazine concentrations in samples collected in May from 1991 through 2006 in the lower Missouri River 


\section{Conversion Factors}

\begin{tabular}{lll}
\multicolumn{1}{c}{ MI to Inch/Pound } & \multicolumn{1}{c}{ To obtain } \\
\hline & \multicolumn{1}{c}{ Length } & \\
\hline millimeter $(\mathrm{mm})$ & 0.03937 & inch (in.) \\
kilometer $(\mathrm{km})$ & 0.6214 & mile (mi) \\
\hline & Volume & \\
\hline liter $(\mathrm{L})$ & 1.057 & quart (qt) \\
liter $(\mathrm{L})$ & 0.2642 & gallon (gal) \\
\hline & \multicolumn{1}{c}{ Mass } & \\
\hline microgram $(\mu \mathrm{g})$ & 0.00000003527 & ounce, avoirdupois $(\mathrm{oz})$ \\
milligram $(\mathrm{mg})$ & 0.00003527 & ounce, avoirdupois $(\mathrm{oz})$ \\
gram $(\mathrm{g})$ & 0.03527 & ounce, avoirdupois $(\mathrm{oz})$ \\
kilogram $(\mathrm{kg})$ & 2.205 & pound avoirdupois $(\mathrm{lb})$ \\
\hline
\end{tabular}

Temperature in degrees Celsius $\left({ }^{\circ} \mathrm{C}\right)$ may be converted to degrees Fahrenheit $\left({ }^{\circ} \mathrm{F}\right)$ as follows:

${ }^{\circ} \mathrm{F}=\left(1.8 x^{\circ} \mathrm{C}\right)+32$

Temperature in degrees Fahrenheit $\left({ }^{\circ} \mathrm{F}\right)$ may be converted to degrees Celsius $\left({ }^{\circ} \mathrm{C}\right)$ as follows:

${ }^{\circ} \mathrm{C}=\left({ }^{\circ} \mathrm{F}-32\right) / 1.8$

Concentrations of chemical constituents in water are given either in milligrams per liter (mg/L) or micrograms per liter $(\mu \mathrm{g} / \mathrm{L})$. 


\title{
Water-Quality Requirements, Tolerances, and Preferences of Pallid Sturgeon (Scaphirhynchus albus) in the Lower Missouri River
}

\author{
By Dale W. Blevins
}

\section{Abstract}

Although numerous studies have been completed on pallid sturgeon populations and behavior, few have addressed the potential for water-quality characteristics to limit recruitment and population success of pallid sturgeon. Literature on sturgeon and water-quality data indicates recruitment of pallid sturgeon may be limited by several water-quality characteristics of the lower Missouri River including:

- High summer water temperatures in excess of 30 degrees Celsius, which likely are stressful to pallid sturgeon,

- Turbidities that are more than an order of magnitude less than the unaltered Missouri River and may no longer provide adequate cover for egg, larval, and young pallid sturgeon or for older pallid sturgeon attempting to capture prey,

- Dissolved oxygen that decreases to concentrations less than 2 milligrams per liter during some river rises in the late spring and summer,

- Food webs altered by increased light availability and hypereutrophic conditions caused by or enhanced by impoundment, bank stabilization, nonnative species, and decreased allocthanous material from the basin,

- Bioaccumulative contaminants, including polychlorinated biphenyls, chlordane, dichlorodiphenyltrichloroethane (DDT) and its metabolites, mercury, and synergistic contaminant cocktails that are particularly damaging to long-lived fish, and

- Other contaminants such as agricultural chemicals (particularly atrazine) and organic wastewater compounds that can disrupt endocrine systems of fish and limit reproduction at extremely low concentrations.

Additional research could be used to characterize and quantify the requirements, tolerance, and preferences of pallid sturgeon to these water-quality characteristics, especially during the egg and larval life stages. Enhancements to existing water-sampling programs are needed to quantify the exposure of pallid sturgeon to many of these water-quality stressors.

\section{Introduction and Purpose}

Currently (2011), the pallid sturgeon (Scaphirhynchus albus) has been listed by the U.S. Fish and Wildlife Service as an endangered species (U.S. Fish and Wildlife Service, 1990). The paucity of larval pallid sturgeon captures (Kallemeyn and Novotmy, 1977 and Hesse and Mestl, 1988 in Keenlyne, 1989) and the limited number of young wild pallid sturgeon in the lower Missouri River (downstream from Gavins Point Dam, S. Dak., fig. 1) (U.S. Fish and Wildlife Service, 2006; Barada and Steffensen, 2006; Kennedy and others, 2006; Steffensen and Barada, 2006; Utrup and others, 2006) indicate sporadic or limited natural recruitment may be a primary contributor to the decline of pallid sturgeon. Water quality has been hypothesized to be a potential cause or contributor to the lack of pallid sturgeon recruitment in the lower Missouri River (U.S. Fish and Wildlife Service, 2006). Water quality encompasses a wide range of characteristics that may be associated with potential recruitment bottlenecks. These include habitat characteristics (such as water temperature, dissolved oxygen, and light), food-web constituents (such as nutrients, plankton, light, and organic material), and toxic contaminants (such as bioaccumulative compounds, hormones, and endocrine disruptors). Therefore, this report, prepared by the U.S. Geological Survey, in cooperation with U.S. Army Corps of Engineers, contains a review of literature associated with water-quality requirements, tolerances, and preferences of pallid sturgeon and related species, to narrow the scope of ongoing lower Missouri River investigations and identify needed areas of research in this wide and diverse field of study. In the few cases where water-quality requirements of pallid sturgeon are at least partially documented and corresponding water-quality data exist for the lower Missouri River, comparisons are made to assess potential hazards to pallid-sturgeon recruitment. 
Although some research into the water-quality requirements of the pallid sturgeon has recently (2011) begun, little has been published. Consequently, information from other sturgeon species, especially the closely related shovelnose sturgeon (Scaphirhynchus platorynchus), and other lower Missouri River fish species, are used as indicators of waterquality tolerances when little or no data are available on pallid sturgeon. Shovelnose and pallid sturgeon are so closely related that hybridization has been genetically documented (Tranah and others, 2004). However, there are at least three genetically distinct populations of pallid sturgeon (U.S. Fish and Wildlife Service, 2006): the upper Missouri River (upstream from Lake Sakakawea, fig. 1), the lower Missouri/middle Mississippi, and the Atchafalaya River reaches. The genetic difference between the upper Missouri River population and the Atchafalaya population was determined to be almost as great as the genetic difference between the pallid and shovelnose sturgeon (Campton and others, 2000). Consequently, water-quality requirements of pallid sturgeon in the upper Missouri River, which have been isolated since the early 1950s, may not necessarily be the same as pallid sturgeon in the lower Missouri River. Nevertheless, data from upper Missouri River pallid and other sturgeon species often are the best available indicators of water-quality requirements for pallid sturgeon in the lower Missouri River and are, therefore, included in this report.

\section{Requirements, Tolerances, and Preferences for Water-Quality Habitat Characteristics}

Many water-quality measurements include a number of properties and characteristics of water that are considered fish-habitat characteristics. Following are responses of various sturgeon species to these habitat characteristics as described in the literature, comparisons to any corresponding data available on the lower Missouri River, and areas of missing data or insufficient investigation.

\section{Water Temperature}

In a review of papers on the environmental requirements of North American sturgeon, Cech and Doroshov (2004) concluded that most sturgeon prefer and perform optimally under cool [less than 25 degrees Celsius $\left({ }^{\circ} \mathrm{C}\right)$ ] temperatures. Activity and growth of young sturgeons generally increase with temperature until an optimal temperature is reached, usually below $25^{\circ} \mathrm{C}$. Lake (Acipenser fulvescens), White (Acipenser transmontanus), Atlantic (Acipenser oxyrinchus), and Green (Acipenser medirostris) sturgeon experience optimal growth between 15 and $25^{\circ} \mathrm{C}$. Young life-history stages may be the most temperature sensitive within sturgeon species. Gulf of Mexico sturgeon eggs, embryos, and larvae have the highest survival rates at 15 to $20^{\circ} \mathrm{C}$, but survival decreased significantly at temperatures greater than $25^{\circ} \mathrm{C}$ (Chapman and Carr, 1995). Hatching rates of lake and white sturgeon decreased at temperatures greater than $20^{\circ} \mathrm{C}$ and ceased above $23^{\circ} \mathrm{C}$ (Wang and others, 1985). Another laboratory experiment indicated that larval survival decreased dramatically at temperatures greater than $20^{\circ} \mathrm{C}$ (Wang and others, 1987). In general, the results of laboratory studies on early life stages are in good agreement with the field observations on spawning temperature ranges of several stocks (Cech and Doroshov, 2004).

A study of 1,000 juvenile [ 65 to 258 millimeters ( $\mathrm{mm}$ ) and 0.90 to 67.0 grams $(\mathrm{g})]$ shovelnose sturgeon in the upper Missouri River concluded that optimal growth and feeding efficiency occurred at about $22.0^{\circ} \mathrm{C}$ (Kapperman and others, 2009). Mortality rates increased as temperatures increased from 22 to $30^{\circ} \mathrm{C}$ (the highest temperature tested), but mortality at $30^{\circ} \mathrm{C}$ was only about 3 percent after 89 days. They also concluded that the minimum temperature for growth was $10.0^{\circ} \mathrm{C}$, implying that decreased temperatures below upper Missouri River dams with hypolimnetic releases may decrease growth and populations of shovelnose sturgeon.

A small laboratory study on 18 juvenile (18 to $38 \mathrm{~g}$ ) pallid sturgeon from the upper Missouri River indicate that optimal temperatures for feeding and growth occur at a substantially higher temperature than shovelnose sturgeon $\left(28^{\circ} \mathrm{C}\right)$ and no lethality occurs below $29^{\circ} \mathrm{C}$ (Chipps and others, 2010). However, after a 4-day immersion in $33^{\circ} \mathrm{C}$ water, one of six pallid sturgeons died, and all six fish died after only 2 hours at $35^{\circ} \mathrm{C}$. Although the sample size was small and the length of exposure was limited to 4 days, these data indicate that pallid sturgeon actually prefer water temperatures as high as $28^{\circ} \mathrm{C}$, begin to suffer between 30 and $33^{\circ} \mathrm{C}$, and start to die at temperatures greater than $33^{\circ} \mathrm{C}$. It is possible, if not likely, that pallid sturgeons in embryonic and larval stages are even less tolerant of high temperatures.

\section{Water Temperatures of the Lower Missouri River}

Continuous water-temperature data collected at seven streamflow-gaging stations on the lower Missouri River from 2006 through 2009 (http://nwis.waterdata.usgs.gov/mo/nwis/) document a continuous increase in mean July and August water temperatures with distance downstream from Yankton, S. Dak. (near Gavins Point Dam) to Waverly, Mo. (table 1). The $1.0^{\circ} \mathrm{C}$ increase between Yankton, S. Dak. and Sioux City, Iowa occurred as cool water released from Lewis and Clark Lake (fig. 1) equilibrated to mean air temperatures, whereas the increases that occurred between Sioux City and Waverly were caused by the increase in ambient air temperatures that occurs with decreasing latitude. The July and August temperature changes between the three most downstream stations (Waverly, Boonville, and Hermann, Mo.) were small because these stations are at similar latitudes. Mean July and August water temperatures at the three lowest Missouri River stations during this period were near the juvenile-pallid optimal temperature of $28^{\circ} \mathrm{C}$ (Chipps and others, 2010), and the maximum 


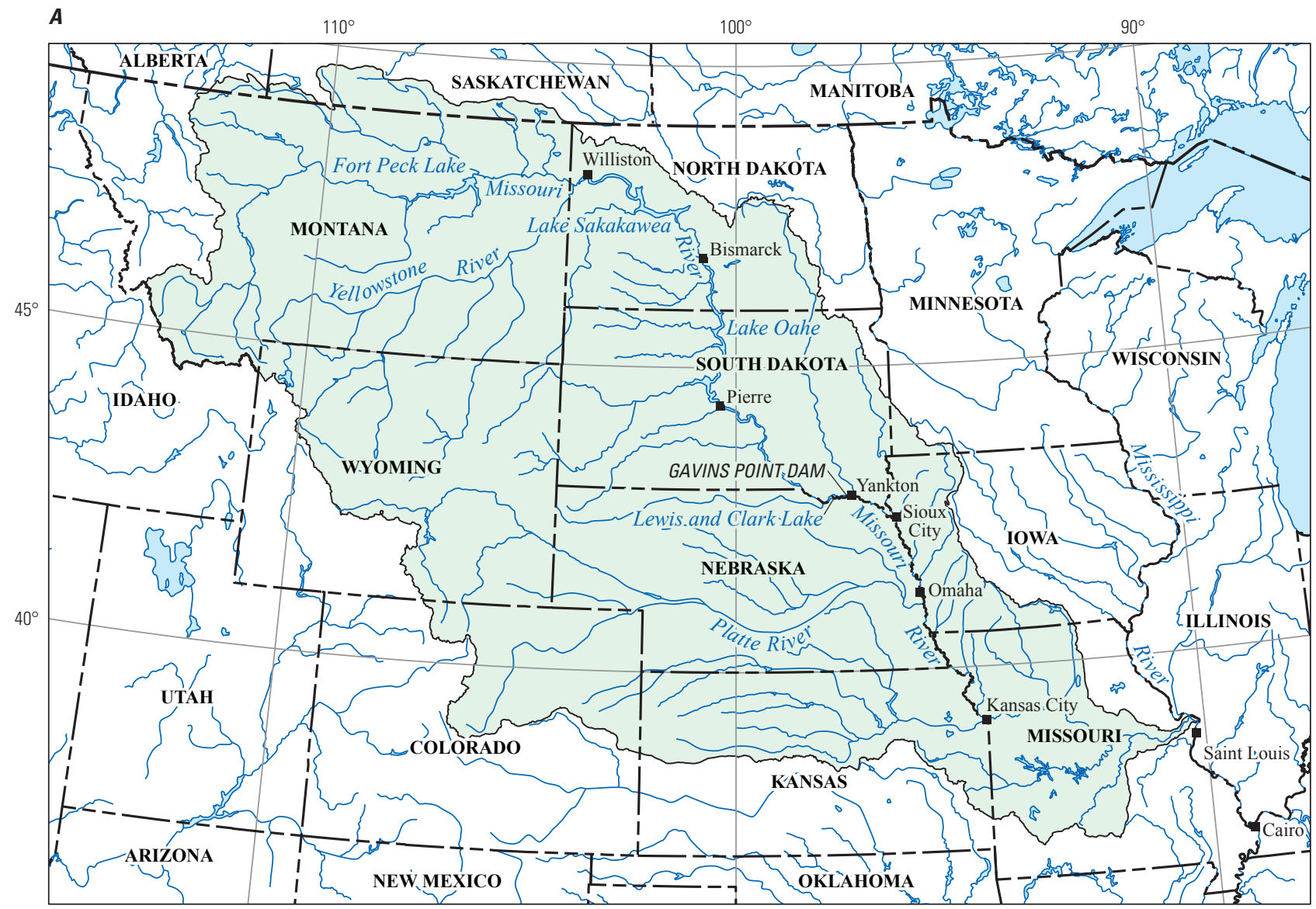

Base from U.S. Geological Survey digital data, 2001, $\quad 0 \quad 100 \quad 200 \quad 300 \quad 400$ MILES $1: 2,000,000$

Albers Equal-area Conic projection

Standard parallels $29^{\circ} 30^{\prime} \mathrm{N}$ and $45^{\circ} \mathrm{N}$

Central meridian $100^{\circ} \mathrm{W}$

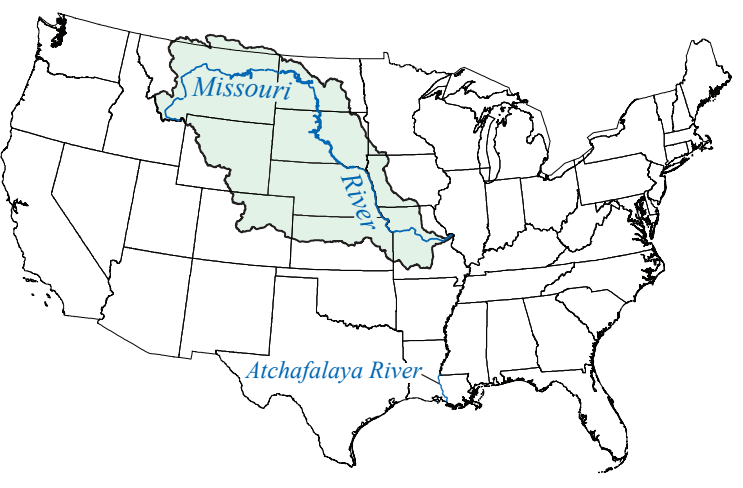

EXPLANATION

Missouri River Basin

- U.S. Geological streamflow-gaging station

- Location referred to in text

Figure 1. A, Location of Missouri River Basin, and $B$, location of streamflow-gaging stations along the lower Missouri River downstream from Gavins Point Dam, S. Dak.

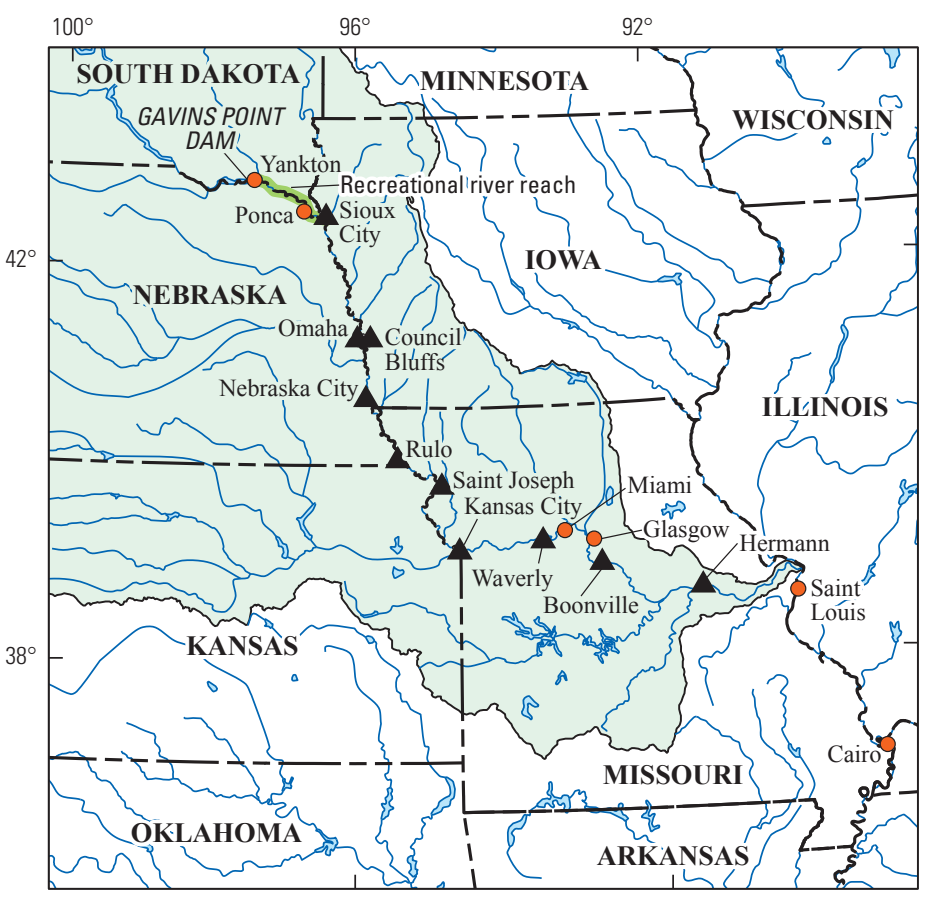

Base from U.S. Geological Survey digital data, 2001, 1:2,000,000 Albers Equal-area Conic projection

Standard parallels $29^{\circ} 30^{\prime} \mathrm{N}$ and $45^{\circ} \mathrm{N}$, central meridian $100^{\circ} \mathrm{W}$

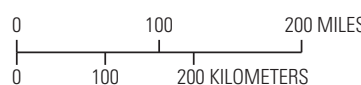


Table 1. Mean, maximum, and minimum water temperatures during July and August at seven streamflow-gaging stations on the lower Missouri River from 2006 through 2009.

$\left[{ }^{\circ} \mathrm{C}\right.$, degrees Celsius; $\mathrm{NA}$, data not available]

\begin{tabular}{|c|c|c|c|c|c|c|c|c|c|c|c|c|c|}
\hline $\begin{array}{l}\text { Station } \\
\text { location }\end{array}$ & $\begin{array}{c}\text { Mean } \\
\text { tempera- } \\
\text { ture } \\
\left(\text { in }^{\circ} \mathrm{C}\right)\end{array}$ & $\begin{array}{c}\text { Mean } \\
\text { daily } \\
\text { maximum } \\
\text { tempera- } \\
\text { ture } \\
\left(\text { in }^{\circ} \mathrm{C}\right)\end{array}$ & $\begin{array}{l}\text { Mean daily } \\
\text { minimum } \\
\text { temperature } \\
\left.\text { (in }{ }^{\circ} \mathrm{C}\right)\end{array}$ & $\begin{array}{c}\text { Instan- } \\
\text { taneous } \\
\text { maximum } \\
\text { (in }{ }^{\circ} \mathrm{C} \text { ) }\end{array}$ & $\begin{array}{c}\text { Mean } \\
\text { number of } \\
\text { days with } \\
\text { daily mean } \\
\text { water tem- } \\
\text { peratures } \\
\text { of } 28.0^{\circ} \mathrm{C} \\
\text { or greater }\end{array}$ & $\begin{array}{c}\text { Mean } \\
\text { number } \\
\text { of days } \\
\text { with daily } \\
\text { maximum } \\
\text { water tem- } \\
\text { peratures } \\
\text { of } 28.0^{\circ} \mathrm{C} \\
\text { or greater }\end{array}$ & $\begin{array}{c}\text { Mean } \\
\text { number } \\
\text { of days } \\
\text { with daily } \\
\text { minimum } \\
\text { water tem- } \\
\text { peratures } \\
\text { of } 28.0^{\circ} \mathrm{C} \\
\text { or greater }\end{array}$ & $\begin{array}{c}\text { Mean } \\
\text { number of } \\
\text { days with } \\
\text { daily mean } \\
\text { water tem- } \\
\text { peratures } \\
\text { of } 30.0^{\circ} \mathrm{C} \\
\text { or greater }\end{array}$ & $\begin{array}{c}\text { Mean } \\
\text { number } \\
\text { of days } \\
\text { with daily } \\
\text { maximum } \\
\text { water tem- } \\
\text { peratures } \\
\text { of } 30.0^{\circ} \mathrm{C} \\
\text { or greater }\end{array}$ & $\begin{array}{c}\text { Mean } \\
\text { number } \\
\text { of days } \\
\text { with daily } \\
\text { minimum } \\
\text { water tem- } \\
\text { peratures } \\
\text { of } 30.0^{\circ} \mathrm{C} \\
\text { or greater }\end{array}$ & $\begin{array}{c}\text { Mean } \\
\text { number of } \\
\text { days with } \\
\text { daily mean } \\
\text { water tem- } \\
\text { peratures } \\
\text { of } 31.0^{\circ} \mathrm{C} \\
\text { or greater }\end{array}$ & $\begin{array}{c}\text { Mean } \\
\text { number } \\
\text { of days } \\
\text { with daily } \\
\text { maximum } \\
\text { water tem- } \\
\text { peratures } \\
\text { of } 31.0^{\circ} \mathrm{C} \\
\text { or greater }\end{array}$ & $\begin{array}{c}\text { Mean } \\
\text { number } \\
\text { of days } \\
\text { with daily } \\
\text { minimum } \\
\text { water tem- } \\
\text { peratures } \\
\text { of } 31.0^{\circ} \mathrm{C} \\
\text { or greater }\end{array}$ \\
\hline $\begin{array}{l}\text { Yankton, } \\
\text { S. Dak. }\end{array}$ & 24.6 & 26.8 & 23.0 & 28.3 & 0 & 1 & 0 & 0 & 0 & 0 & 0 & 0 & 0 \\
\hline $\begin{array}{l}\text { Sioux City, } \\
\text { Iowa }\end{array}$ & 25.6 & NA & NA & NA & 2 & NA & NA & 0 & NA & NA & 0 & 0 & 0 \\
\hline $\begin{array}{l}\text { Council } \\
\text { Bluffs, } \\
\text { Iowa }\end{array}$ & 26.4 & NA & NA & NA & 12 & NA & NA & 0 & NA & NA & 0 & 0 & 0 \\
\hline $\begin{array}{l}\text { St. Joseph, } \\
\text { Mo. }\end{array}$ & 27.3 & 29.8 & 24.4 & 31.2 & 22 & 28 & 19 & 1.5 & 5.8 & 1.0 & 0 & 0.8 & 0 \\
\hline $\begin{array}{c}\text { Waverly, } \\
\text { Mo. }\end{array}$ & 27.9 & 30.5 & 24.6 & 32.5 & 31 & 36 & 25 & 8.5 & 12 & 5.8 & 1.3 & 3.3 & .8 \\
\hline $\begin{array}{c}\text { Boonville, } \\
\text { Mo. }\end{array}$ & 27.7 & 30.3 & 24.2 & 32.0 & 27 & 33 & 24 & 7.8 & 11 & 5.0 & 1.3 & 4 & .5 \\
\hline $\begin{array}{l}\text { Hermann, } \\
\text { Mo. }\end{array}$ & 27.6 & 30.2 & 24.2 & 32.1 & 27 & 32 & 21 & 7.3 & 11 & 3.8 & 1.5 & 2.5 & .3 \\
\hline
\end{tabular}


instantaneous main channel observed water temperature from 2006 through 2009 was $32.5^{\circ} \mathrm{C}$. The highest daily mean temperature recorded at Boonville from 1953 to 1964 was $32.2^{\circ} \mathrm{C}$, which occurred for 3 continuous days in July and August of 1955 (Bowie, 1971). A daily mean temperature of $32.2^{\circ} \mathrm{C}$ would imply a maximum instantaneous water temperature in excess of $33^{\circ} \mathrm{C}$, the temperature that Chipps and others (2010) determined juvenile pallid sturgeon began to die. Water temperatures greater than $30.0^{\circ} \mathrm{C}$ tend to occur on consecutive days in the lower Missouri River (Bowie, 1971 and Blevins and others, 2007), which makes temperature stress more severe. From St. Joseph, Mo. downstream, temperatures between 30 and $32^{\circ} \mathrm{C}$ occur most years, which is the range that temperature stress may begin for juvenile pallid sturgeon. The four stations from St. Joseph to Hermann, Mo. had an average of 2 to 9 days per year with daily mean temperatures of $30.0^{\circ} \mathrm{C}$ or more during the 4 years from 2006 through 2009. The maximum was 18 days at Waverly in 2006. These data indicate that during warmer summers, maximum daily temperatures in the Missouri River downstream from St. Joseph approach lethality for juvenile pallid. Increases in summer water temperatures that may result from global climate change may push ambient water temperatures beyond tolerable limits. Pallid sturgeon in the egg and larval stages may have even lower temperature tolerance. If so, summer spawns downstream from St. Joseph, which have now been documented (U.S. Fish and Wildlife Service, 2006), may already be suffering from high water temperatures.

\section{Migration Temperature Cues and Growing Season Length}

Water temperature and increased streamflow are expected cues for pallid sturgeon migration and spawning in the Missouri River (U.S. Fish and Wildlife Service, 2000). These two cues generally occur concurrently, so separation is difficult. Although several studies have evaluated the effects of temperature on the migration of other sturgeon species, no studies or data have been published to verify, quantify, or separate the effects of these two cues on pallid sturgeon migration. The temperatures cueing upstream migration of other North American sturgeon species varies widely (from 3 to $20^{\circ} \mathrm{C}$ ) depending on the climate where a given species lives (Cech and Doroshov, 2004). To look at the relative differences in dates of spring migration with distance on the lower Missouri River as determined by temperature, table 2 was compiled assuming spring migrations cannot begin until water temperatures exceed an arbitrary value of $10^{\circ} \mathrm{C}$. The first day of each year with a daily mean water temperature of $10^{\circ} \mathrm{C}$ or greater for each of seven stations on the lower Missouri River for the years from 2006 through 2009 are listed in table 2. As with mean temperatures, the mean first day of $10^{\circ} \mathrm{C}$ or greater water temperatures at the lower three stations was almost identical (March 22 or 23), but advanced substantially (by 34 days) upstream (northward) from Waverly (March 22) to Yankton
(April 18). The growing season, as defined by the part of the year between the first occurrence of $10^{\circ} \mathrm{C}$ temperatures in the spring and the first occurrence of temperatures below $10^{\circ} \mathrm{C}$ in the fall, also is shown in table 2 and indicates a similar pattern to first occurrence of migration temperatures. The lower three stations have similar growing seasons (232 to 236 days), but growing season decreased by 19 percent upstream (northward) from Waverly (232 days) to Yankton (188 days). These data indicate that pallid sturgeon in the lower Missouri River can extend their growing season by swimming downstream to Kansas City where the river turns eastward and becomes parallel in latitude. However, there would be little growing-season advantage of swimming the 330 miles from Kansas City to the mouth near St. Louis, Mo. Conversely, pallid sturgeon could find relief from high summer temperatures by swimming upstream (northward) from Kansas City, but would gain little by swimming the 330 miles upstream from the mouth of the Missouri River.

Given the frequent nature of water temperatures greater than those preferred by other sturgeon species in the lower Missouri River and the abundance of pallid sturgeon in the even warmer lower Mississippi River, pallid sturgeon likely have evolved to higher water temperatures than other sturgeon species. However, continuous temperature measurements in the main channel of the lower Missouri River [typically the coolest part of the river (Kelly and others, 2006)] indicate that water temperature often may be in the stressful range for juvenile pallid sturgeon during unusually warm summers. The egg and larval stages likely are even more sensitive to these high temperatures. Adult pallid sturgeon might be able to find temperature relief by moving toward the northern end of the lower Missouri River, finding pockets of slightly cooler water, or finding cooler tributaries [although most tributaries of the lower Missouri River likely are hotter than the Missouri River in the summer because of their smaller size (Bowie, 1971)]. However, drifting larvae have no ability to escape these higher temperatures, which could limit recruitment in abnormally hot summers. Temperature constraints could be expected to get worse if summer air temperatures in the Missouri River Basin increase in the coming decades as global climate models predict (Intergovernmental Panel on Climate Change, 2007). Therefore, more and larger studies on the temperature preferences and tolerances of pallid sturgeon at younger life stages are needed to determine whether ambient water temperatures can limit the recruitment of pallid sturgeon in the Missouri River now (2011) and in the future.

Although instantaneous measurements of water temperature are available from numerous sources and for many decades, only continuous measurements can provide daily mean, maximum, and minimum temperatures. Continuous water-temperature monitoring data have become available since 2006 at several lower Missouri River stations. Because water temperature likely is an important cue for sturgeon migration and spawning, peak summer water temperatures in the lower part of the river may be stressful for pallid sturgeon, and the available period of record is short; continuous 
Table 2. First day, last day, and length of growing season of pallid sturgeon at stations on the lower Missouri River from 2006 through 2009.

[Growing season is defined as beginning the first day with a daily mean water temperature of $10^{\circ} \mathrm{C}$ or greater and ending the last day with temperatures of $10^{\circ} \mathrm{C}$ or greater. $\mathrm{NC}$, not computed]

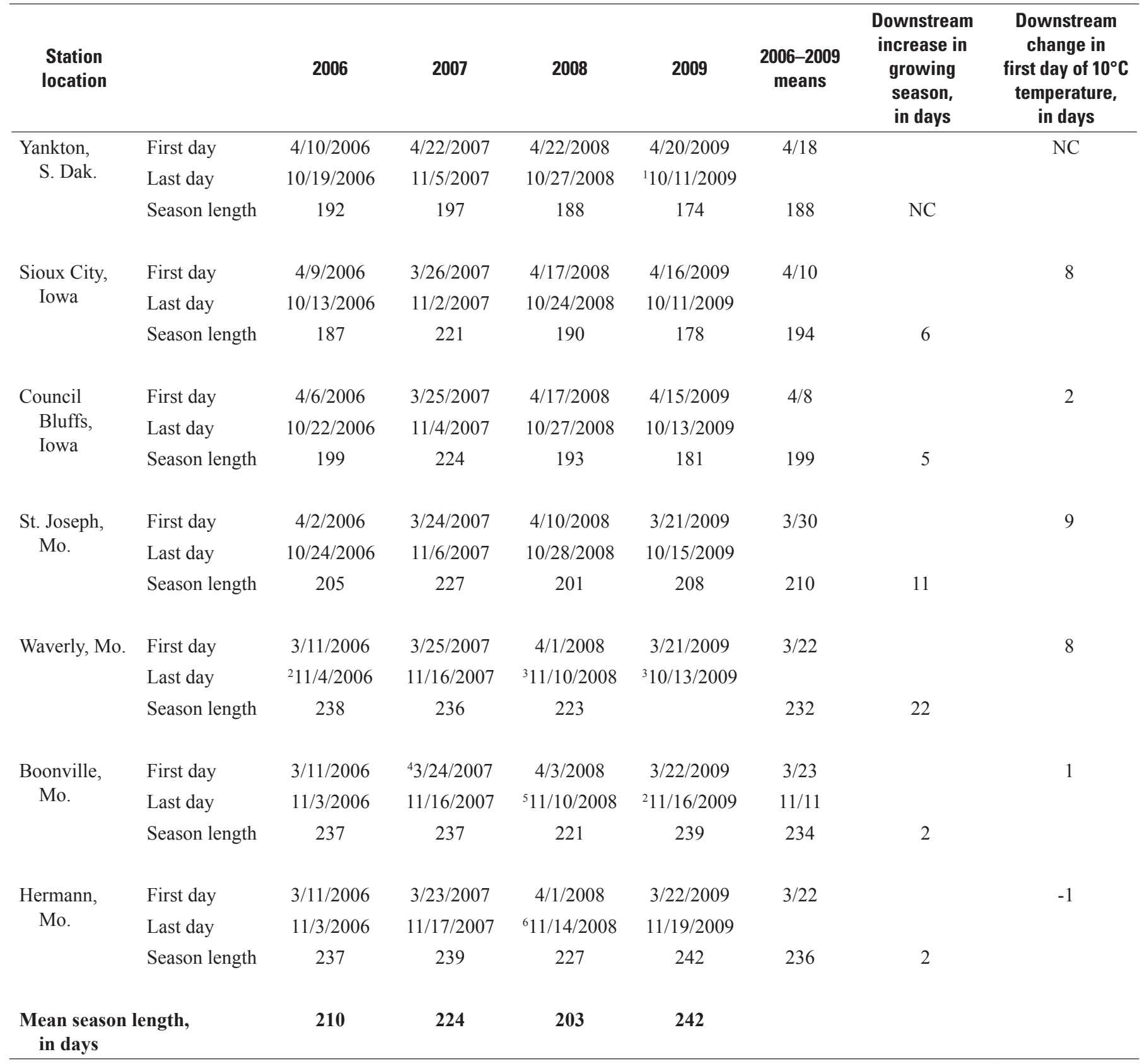

${ }^{1}$ Used end date from Sioux City, Iowa as estimate for end date at Yankton, S. Dak.

${ }^{2}$ Temperature recorders were removed before daily mean temperatures decreased below $10.0^{\circ} \mathrm{C}$. Therefore, the actual end date of the growing season was later and the growing season slightly longer than computed.

${ }^{3}$ Date interpolated from data collected at Kansas City and Glasgow, Mo.

${ }^{4}$ Date interpolated from data collected at Boonville and Hermann, Mo.

${ }^{5}$ Date interpolated from data collected at Glasgow and Jefferson City, Mo.

${ }^{6}$ Date interpolated from data collected at Jefferson City and St. Charles, Mo. 
water-temperature monitoring from March through September is needed at enough stations to provide a longitudinal resolution of $1.0^{\circ} \mathrm{C}$ or less. Data from Chipps and others (2010) indicate that when temperatures are near $32^{\circ} \mathrm{C}$, even a $0.5^{\circ} \mathrm{C}$ temperature change may be important for pallid sturgeon survival.

\section{Salinity}

Although the specific conductance and dissolved-solids content of the Missouri River is greater than that in many rivers (Pillsbury, 1981), pallid sturgeon appear to have a tolerance of much greater salinities. They have been collected from brackish water in the lower Mississippi River and near the mouth of the Atchafalaya River in Louisiana (Keenlyne, 1989; Vladykov and Greely, 1963).

\section{Turbidity, Light, and Predation}

Missouri River fish evolved under high-turbidity conditions (Pfleiger and Grace, 1987 and Blevins, 2006). In the first documentation of the pallid sturgeon as a separate species in 1905, Forbes and Richardson (1905) observed that pallid sturgeon were better adapted to the muddier Missouri River than the less turbid upper Mississippi River. Subsequently, many others have noted that pallid sturgeon prefer dimly lit, turbid water and typically do not use tributaries or clear-water riverine habitats that are frequented by shovelnose sturgeon (Cech and Doroshov, 2004; Carlson and others, 1985; Mayden and Kuhajda, 1997; and Erickson, 1992). Light intensity and photoperiod affect behavior, growth, and reproduction of fish, yet little information is available on decreased turbidity as a threat to pallid sturgeon. Although pallid sturgeon are well adapted to highly turbid conditions, it has long been known that turbid conditions typically are a limiting factor to other aquatic life in the Missouri River (Berner, 1951 and Ellis, 1937). The decrease in turbidity likely causes openings for species that could compete with or prey on pallid sturgeon. Because larval sturgeon are small, they are particularly susceptible to mortality from predation (Wilhaber and others, 2007). However, increased water clarity and artificially high densities of predatory fishes have been implicated as possible limitations in sustaining pallid sturgeon populations (U.S. Fish and Wildlife Service, 2006). Sturgeons rely heavily on chemosensory mechanisms, olfaction, and gustation for finding food (Kasumyan, 2002). Shovelnose retinas have long and tightly packed rods, which may have value for light intensity discrimination and orienting behavior in dimly lit environments (Sillman and others, 1999).

Carlson and others (1985) indicated that the diets of adult shovelnose and pallid sturgeon consist mostly of the immature stages of insects, but a greater proportion of fish (mostly cyprinids) was reported in the diets of pallid sturgeon. Grohs and others (2009) determined that pallid sturgeon undergo an ontogenetic shift from macroinvertebrates to piscivory at about 600 millimeters in length or 5 to 7 years of age. Cross (1967) also reported a greater incidence of fish in the diet of pallid sturgeon, although many other investigators have reported a low incidence of fish in the diet of shovelnose sturgeon (Carlson and others, 1985). Fathead minnows (Pimephales promelas) and sturgeon chub (Macrhybopsis gelida) are important prey species of pallid sturgeon (Gerrity and others, 2006). Pallid sturgeon in the lower channelized part of the Missouri River seldom reach 15 pounds $(6.8 \mathrm{~kg})$, but pallid sturgeon above the impoundments are seldom less than that weight, indicating a potential food shortage in the channelized river, as postulated by Whitley and Campbell (1974), and Hesse (1987). The decline in body condition of the pallid and shovelnose sturgeon as the reservoirs filled indicate that food sources became a problem through the reduction of productivity (Keenlyne, 1989). This reduction in food sources may well have been caused by the large change in the food web imposed by decreased turbidity and other habitat changes caused by upstream impoundments and bank stabilization activities (Russell, 1986; Unkenholz, 1986; and Hesse, 1987). This possible decrease in food sources would have occurred in response to decreases in decomposition of allocthanous material, in spite of likely increases in trophic condition. With impoundment, the camouflaging advantage of turbidity in capturing prey decreases along with the occurrence of many aquatic insects (Keenlyne, 1989). The infrequent use of the Missouri River by pallid sturgeon upstream from the mouth of the Yellowstone River indicates that the effect of Fort Peck Lake (fig. 1) has made turbidity, hydrograph character, temperature, sediment and organic-matter transport more like the less turbid conditions upstream from the pallid sturgeon's native range (Bramblett and White, 2001). Pallid and shovelnose sturgeon avoid the clear-water, impounded areas of the system, where visually oriented, nonnative species are favored (Bramblett and White, 2001). Pallid sturgeon may become more nocturnal in areas of decreased turbidity (Bramblett and White, 2001 and Erickson, 1992), thus altering their ability to find food.

A recent laboratory study indicated little predation of juvenile pallid sturgeon (length 40 to $100 \mathrm{~mm}$ ) in bare tanks by walleye (Sander vitreus) and small-mouth bass (Micropterus dolomieu), when given a choice between pallid sturgeon and fathead minnows (French, 2010). Both predators captured flathead minnows and juvenile pallid sturgeon, but usually spit out the pallid sturgeon, but consumed the flathead minnows. Flathead catfish (Pylodictis olivaris) displayed neutral selection for pallid sturgeon at low sturgeon densities (20 per tank), but negative selection at higher densities ( 40 per tank). Flathead catfish preferred small pallid sturgeon ( 40 to $50 \mathrm{~mm}$ ) to larger juvenile pallid sturgeon ( 75 to $100 \mathrm{~mm}$ ). The author concluded that juvenile pallid sturgeons have inherent physical or chemical resistance to predation. Predation vulnerability of pallid sturgeon to all three predators consistently was negative for pallid sturgeon at turbidities of 0 to 3 and 70 to 91 NTU (nephelometric turbidity units). However, 70 to 91 NTU is slightly less than the post-impoundment median turbidity in the lower Missouri River. The 2006 through 2009 
median daily mean turbidity at Hermann, Mo. for the months of March through October (daily mean turbidity values are available from the U.S. Geological Survey National Water Information System at http://nwis.waterdata.usgs.gov/mo/ $n w i s / d v /$ ? referred_module $=q w$ ) was $100 \mathrm{NTU}$ and was more than an order of magnitude less than turbidities in the lower Missouri River before impoundments and bank stabilization (Blevins, 2006). Therefore, this study indicates that although juvenile pallid sturgeons have strong inherent protections against predation, post-impoundment turbidities are not large enough to provide adequate protection from predators such as flathead catfish. Also, there are no studies on the vulnerability of larval or early juvenile (less than $40 \mathrm{~mm}$ ) pallid sturgeon to predation at decreased turbidities. A small percentage of stocked 11- to 17-day old pallid-sturgeon fry were determined to survive to the next year on the upper Missouri River, providing a small amount of evidence that the limitation on natural recruitment may be in the egg stage or the first 2 weeks after hatch (Braaten and others, 2008). If so, low turbidity may contribute to predation of eggs or drifting larvae.

Because order-of-magnitude decreases in turbidity may have powerful effects, both direct and indirect, on pallid sturgeon recruitment, field studies and more comprehensive laboratory experiments on the effects of decreased turbidity on spawning behavior and the susceptibility of pallid sturgeon to piscivory, especially at the egg and larval stages, are needed to assess the effects of this fundamental change in the habitat of the pallid sturgeon. Also, field studies on the preference of spawning, larval, and early juvenile pallid sturgeon for higherturbidity regions of the lower Missouri River, its side channels, and tributaries could shed light on the importance of turbidity to recruitment. Turbidity monitoring is needed to relate field conditions to results of laboratory experiments. Because turbidity varies 2 or 3 orders of magnitude with discharge, continuous turbidity monitoring is necessary to characterize the range of conditions and observe pallid-sturgeon response to short-term changes in turbidity, relate field conditions to results of laboratory experiments, and help quantify productivity in the lower Missouri River.

\section{Dissolved Oxygen}

No studies have been done on the tolerances of pallid sturgeon to oxygen depletion; however, several other sturgeon species are sensitive to hypoxic conditions, which impair their respiratory metabolism, foraging activity, and growth rates. Juvenile and adult white sturgeon displayed significant oxygen-consumption rate decreases and decreased activity with exposure to mild hypoxia (51 percent of air saturation) at temperatures typical for these life stages and at $25^{\circ} \mathrm{C}$ (Crocker and Cech, 1996). This decreased activity may result in decreased food consumption, decreased energy storage, and slower growth. The egg and early-hatch stages are most susceptible to low dissolved-oxygen concentrations (Detlaff and others, 1993). Temperature and dissolved oxygen are primary environmental factors on the rate of embryo development (Jobling, 1995). However, the activity of Atlantic and shortnose sturgeon (Acipenser brevirostrum) did not change with exposure to moderate hypoxia [3 milligrams per liter $(\mathrm{mg} / \mathrm{L})$ at $15^{\circ} \mathrm{C}$ ] (Cech and Doroshov, 2004). Shortnose sturgeon died, regardless of life stage, at dissolved-oxygen concentrations less than $2 \mathrm{mg} / \mathrm{L}$ (Jenkins and others, 1993).

Continuous dissolved-oxygen measurements collected on the lower Missouri River from 2006 through 2009 (data available from the USGS National Water Information System at $h t t p: / /$ waterdata.usgs.gov/mo/nwis/qw) are usually greater than the $5 \mathrm{mg} / \mathrm{L}$ standard for warm-water fish (U.S. Environmental Protection Agency, 1986) except during larger rises in the spring and summer. Turbidity spikes during rises have long been associated with substantial decreases in dissolved oxygen on the Missouri and Mississippi Rivers (Berner, 1951 and Platner, 1946). These turbidity spikes stop the creation of oxygen through algal photosynthesis, while algal respiration and biochemical oxygen demand continue to consume oxygen (fig. 2). Concentrations decreased to less than $2 \mathrm{mg} / \mathrm{L}$ and remained less than $5 \mathrm{mg} / \mathrm{L}$ for several days or more on several rises of the lower Missouri River (Blevins and others, 2007). Increases in algal biomass that occurred after the construction of the upstream reservoirs and resultant large decreases in turbidity in the lower Missouri River have likely exacerbated the size and duration of dissolved-oxygen decreases. Areas of severe oxygen depletion also have been identified in dike pools in the lower Missouri and middle Mississippi Rivers, where larval sturgeon are known to reside (Poulton and Allert, 2011). In 1950, before large-scale wastewater treatment, low dissolved-oxygen concentrations ranging from 2.8 to $5.0 \mathrm{mg} / \mathrm{L}$ also occurred during near-average discharges and at water temperatures ranging from 20 to $26^{\circ} \mathrm{C}$ (Public Health Service, 1952).

Although there have been no studies to determine whether, or how, pallid sturgeon adapt to low dissolvedoxygen conditions, other species of sturgeon have shown severe effects at the concentrations often encountered during Missouri River rises. However, pallid sturgeon may be able find refuge from hypoxia in more oxygenated water in tributaries, clearer backwaters, or side channels during high-water events. Kelly and Rydlund (2006) prepared snapshot maps of dissolved oxygen in three, 2-mile reaches of the Missouri River near Kansas City, Mo. during August 8-10, 2005 by moving a continuous water-quality monitor from bank to bank. There often was a 1 to $2 \mathrm{mg} / \mathrm{L}$ difference within each 2-mile reach with most of the difference occurring between the near bank and the thalweg.

"Pallid sturgeons are thought to spawn in the spring or early summer like other sturgeon species. However, the capture of Scaphirhynchus larvae and post-larvae in the Mississippi River during fall months, as well as spring," indicate "an extended spawning season or a second spawn in the lower latitudes of distribution" (U.S. Fish and Wildlife Service, 2006). Therefore, the dissolved-oxygen decreases on the lower Missouri River can occur while pallid sturgeons are still in 


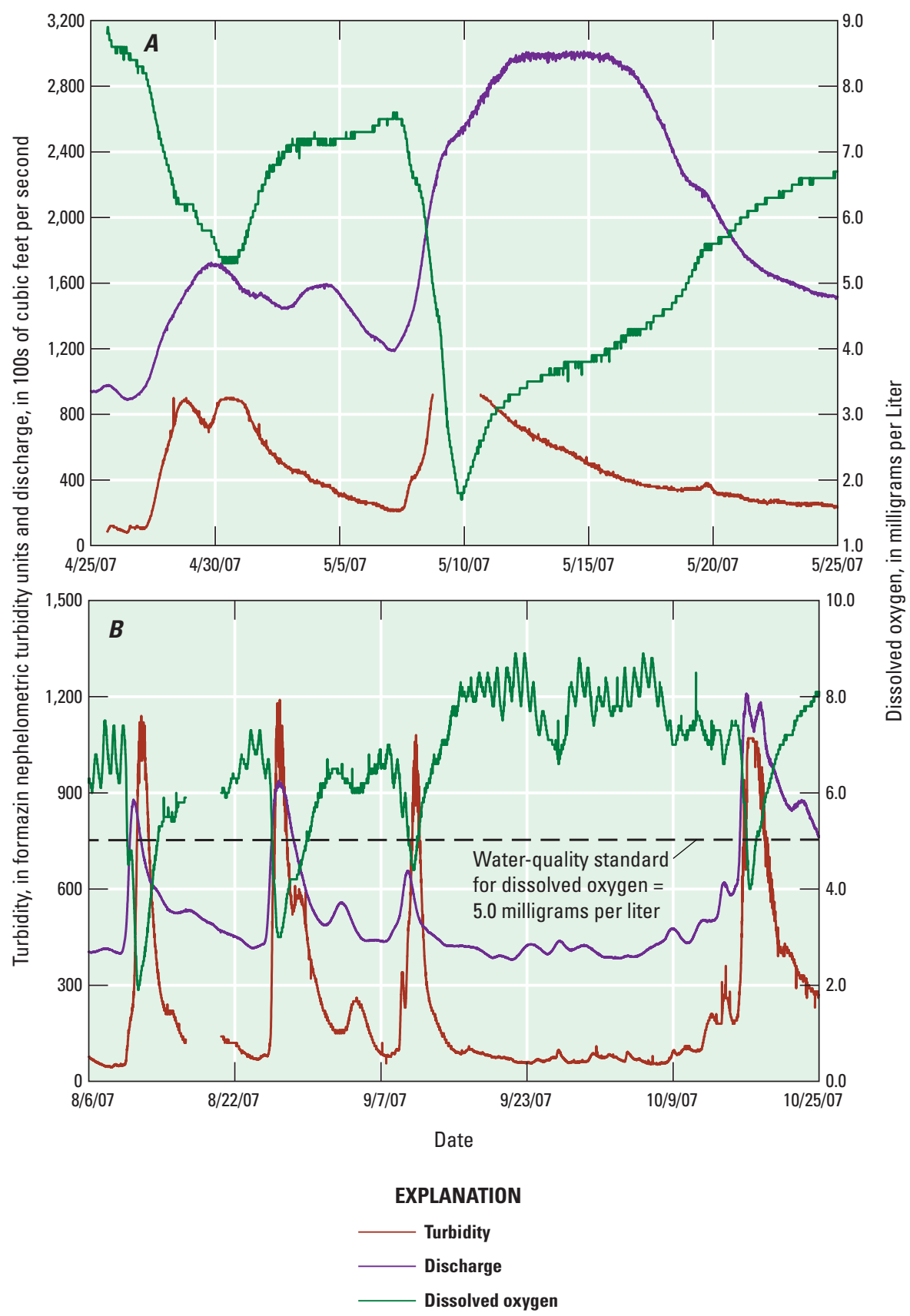

Figure 2. Typical dissolved-oxygen crashes during rises and turbidity peaks on the lower Missouri River. A, Missouri River at Hermann, Mo. B, Missouri River at Waverly, Mo.

their most vulnerable, and largely immobile, egg and larval stages. Later-hatching fry would be especially susceptible to the water-temperature maximums and dissolved-oxygen minimums observed in the summer on the lower Missouri River.

Studies (Crocker and Cech, 1996; Jobling, 1995; and Jenkins and others, 1993) on other species of sturgeon, not in the Missouri River, suggest potential susceptibility to concentrations of less than $3 \mathrm{mg} / \mathrm{L}$ and observed concentrations of dissolved oxygen of less than $2 \mathrm{mg} / \mathrm{L}$ during spring and summer rises indicate a potential hazard to pallid sturgeon, especially at egg and larval life stages (Detlaff and others, 1993). Therefore, laboratory studies on the tolerance of pallid sturgeon to hypoxic conditions at all life stages are needed, as well as field studies of potential methods pallid sturgeon may use to escape from hypoxic events. Real-time, continuous, dissolved-oxygen monitoring on the lower Missouri River would be useful to identify and characterize hypoxic conditions while tagged pallid sturgeon are tracked to determine where they go during periods of low-oxygen stress. 


\section{Requirements and Preferences for Food-Web Water-Quality Constituents}

Because this report focuses only on the water-quality effects on pallid sturgeon, the following discussion is limited to the chemical, microscopic, and small particulate parts of the food web (that can be collected and analyzed in a water sample). Havel and others (2009) classified the trophic level of the lower Missouri River as hypereutrophic based on phosphorus and chlorophyll $a$ concentrations measured in 2004 and 2005. Phytoplankton populations likely are light-limited and are, therefore, much larger and composed of different species than before the reservoirs (Berner, 1951; Public Health Service, 1952; Neel, 1963; and Morris and others, 1968) decreased turbidity by more than an order of magnitude (Blevins, 2006). Because neither nitrogen or phosphorus limit primary production in the lower Missouri River, the large decrease in turbidity likely caused large changes to the food web through increased primary production. The impoundments also decreased concentrations of particulate organic matter and, thus, likely decreased food-web contributions from microbial decomposition of allochthonous material. The U.S. Fish and Wildlife Service (2006) hypothesized that restoration of allochthonous material would have a beneficial trophic effect in the Missouri River and be indirectly beneficial to pallid sturgeon. However, they did not assess the potentially countering effect of increased primary production or consider the modern hypereutrophic condition of the lower Missouri River.

As yet, there is little or no information about the specific food preferences of larval pallid sturgeon. However, firstfeeding larval fish are the most susceptible to food deprivation and plankton are an important food source for most larval fishes. Decreases in densities or size of preferred zooplankton species or a change in the composition of phytoplankton species because of impoundment or competition could impair recruitment of pallid sturgeon, although shovelnose sturgeons, whose adult diets are different from pallid sturgeon, seem to be relatively unaffected. Larval shovelnose sturgeon have been documented to feed on macroinvertebrates (Braaten and others, 2007).

Large phytoplankton populations usually are associated with large zooplankton populations in large rivers (Williams, 1972), although predation of zooplankton can alter this general relation. Large dams and reservoirs also have imposed major changes in the composition of zooplankton of the Missouri River (Havel and others, 2009; Dickerson and others, 2010; Morris and others, 1968; and Cowell, 1967). Large, lentic, crustacean species, primarily cladocerans and copepods, dominate reaches below reservoirs, but disappear exponentially with distance downstream from dams. The smaller rotifers dominate zooplankton in the unimpounded lower river. Rotifer densities in the upper 700 kilometers $(\mathrm{km})$ of the lower Missouri River were comparable to the greatest densities measured in rivers around the world. Williams (1966) also indicated greater densities of rotifers in the relatively clear water exiting Lewis and Clark Lake at Yankton, South Dakota. However, densities were substantially less downstream from Kansas City, Mo. Although rotifers often dominate zooplankton in large unimpounded rivers, they generally are intolerant of turbulent and turbid conditions, and Williams (1966) reported lesser rotifer densities were associated with "highly silty conditions" at two of the three sampled stations on the lower Missouri River. These samples were collected well after the large decrease in turbidity associated with Missouri River impoundment. Therefore, the extremely turbid and turbulent conditions of the unaltered Missouri River had less rotifer densities than the modern lower Missouri River, although rotifers were the most abundant zooplankton before the upstream impoundments were built (Berner, 1951). Statistically, water temperature was the best explanatory variable for rotifer densities in the lower Missouri River, explaining 38 percent of the variability (Havel and others 2009). Jennings (1979) determined most zooplankton occurred downstream from wing dikes, where larval pallid sturgeon are likely to be found, compared to the navigation channel. Generally, alterations to the lower Missouri River likely have increased plankton densities and changed plankton from a heterotrophic community (Berner, 1951) to a more autotrophic community. The recent and large influx of two nonnative Asian carp species that ingest plankton as part of their food source (Kolar and others, 2007) also may take advantage of increased plankton densities and may help limit plankton populations in some parts of the river.

Despite some knowledge about changes to the plankton community primarily caused by impoundments, little data are available on temporal and spatial variation of the numerous species of phytoplankton, zooplankton, and other plankton in the lower Missouri River. Initiation of regular, systematic, and habitat-specific sampling of plankton is needed to characterize the structure, variability, and seasonality of the base of the lower Missouri River food web. Studies are needed to assess how compositional changes may have affected first-feeding larval pallid sturgeon. Continuous turbidity monitoring also is needed to help characterize the modern habitat of the pallid sturgeon, phytoplankton, and zooplankton in the Missouri River.

\section{Tolerances of Toxic Contaminants}

The effects of most toxic contaminants in the lower Missouri River on pallid sturgeon have not been assessed. Neither is it possible to assess the synergistic effects of multiple contaminants on pallid sturgeon with existing data. However, literature describing the effects of some contaminants, known or suspected of being present in the lower Missouri River, is described below. 


\section{Bioaccumulative Contaminants}

In comparison to more short-lived species, the prolonged maturation cycle and the decades-long lifespan of pallid sturgeon likely make this species more susceptible to altered reproductive development and reduced spawning (Quist, 2004) from lipophilic compounds that accumulate in reproductive tissues and eggs (Vodicnik and Peterson, 1985). In a survey of bottom sediments of the Missouri River using a 7-day amphipod toxicity test, Haring and others (2011) indicated that 43 percent of 183 samples were either lethally toxic or inhibited growth. However, chemical screenings of various organic compounds including chlorinated pesticides, polychlorinated biphenyls (PCBs), and polybrominated diphenyl ethers in the toxic samples indicated no concentrations large enough to be toxic individually.

Although the amount of bioaccumulation and the effects of contaminants on pallid sturgeon are largely unknown, Ruelle and Keenlyne (1993, 1994) detected heavy metals (mercury, cadmium, and selenium), PCBs, and several banned pesticides [dichlorodiphenyltrichloroethane (DDT), chlordane, and dieldrin] in the tissues of three pallid sturgeon collected in 1983 and 1988 just downstream from Lake Sakakawea in North Dakota (fig. 1), southeastern Nebraska, and near the mouth of the Yellowstone River in western North Dakota. Many persistent organochlorine contaminants such as chlordane, dieldrin, and metabolites of DDT are still present in the Missouri River from pre-1974 U.S. applications and atmospheric transport from other countries where they continue to be used (Schmitt, 2002, and Ruelle and Keenlyne, 1993). p,p' DDT and its metabolites dichlorodiphenyldichloroethylene (DDE) and dichlorodiphenyldichloroethane (DDD) were found in all four tissues analyzed (muscle, livers, ovaries, and kidneys). Although the effects of DDT on the reproductive health of pallid sturgeon are unknown, DDT and its metabolites can create physiological alterations to the balance of serum amino acids and thyroid activity, and effect the ability of non-sturgeon fish species to withstand stress (White and others, 1983). The concentrations detected in pallid tissue were considered great enough to be of concern, especially in view of concurrent tissue contamination from PCBs and other chemicals (Ruelle and Keenlyne, 1993). Wet weight PCB concentrations in fish ovaries are known to cause reduced survival of developing fish eggs at concentrations ranging from 0.12 to 24 milligrams per kilogram (mg/kg) (Ernst, 1984). The total PCB concentration in the ovaries of the pallid sturgeon from Nebraska was $28.5 \mathrm{mg} / \mathrm{kg}$, and concentrations from the liver and muscle of the pallid sturgeon caught near the mouth of the Yellowstone River were 20.5 and $25.4 \mathrm{mg} / \mathrm{kg}$, respectively. The Food and Drug Administration's (FDA) action level for PCBs in edible fish tissue is $2.0 \mathrm{mg} / \mathrm{kg}$ wet weight. Therefore, PCBs were suspected of causing reproductive or other healthrelated problems in pallid sturgeon (Ruelle and Keenlyne, 1993).
The FDA action level for chlordane in edible fish tissues is $0.3 \mathrm{mg} / \mathrm{kg}$ wet weight. Ovarian tissue of the Nebraska fish had concentrations of $1.30 \mathrm{mg} / \mathrm{kg}$ for gamma chlordane and $1.27 \mathrm{mg} / \mathrm{kg}$ for alpha chlordane and concentrations of transnonachlor of $1.98 \mathrm{mg} / \mathrm{kg}$ (Ruelle and Keenlyne, 1993). The two upper Missouri River pallid sturgeons had concentrations below $0.07 \mathrm{mg} / \mathrm{kg}$ in all tissues analyzed. Chlordane was used heavily for home termite control and was banned by the U.S. Environmental Protection Agency (USEPA) in 1988, but it has a half life of 10 to 20 years (Rostad, 1997) and is persistent in the environment. Because the most intense use of chlordane in the Missouri River Basin was in the more heavily populated areas downstream from Omaha, Nebr., it is not surprising that the Nebraska pallid sturgeon was the only one to contain elevated concentrations of chlordane. Echols and others (2008) sampled depositional sediments in the lower Missouri River from Omaha, Nebr., to Jefferson City, Mo., and determined the greatest concentrations of chlordane, DDE, lindane, dieldrin, endrin, PCBs, polycyclic aromatic hydrocarbons (PAHs), zinc, cadmium, and lead were immediately downstream from Kansas City, Mo. Pallid sturgeons spending time in this reach likely have even greater exposures to bioaccumulative contaminants.

Although all three of the pallid sturgeons had detections of dieldrin, none of them had concentrations greater than the FDA action level in edible fish tissue of $0.3 \mathrm{mg} / \mathrm{kg}$ wet weight. However, the concentration of dieldrin in ovarian tissue in the Nebraska fish was $1.3 \mathrm{mg} / \mathrm{kg}$. In June 1991, Nebraska issued a dieldrin human health advisory for channel catfish (Ictalurus punctatus) and common carp (Cyprinus carpio).

Ruelle and Keenlyne (1993) determined that heavy metals were at background concentrations except for mercury, cadmium, and selenium for pallid sturgeons in the upper Missouri River. Mercury concentrations exceeded the FDA action level for edible tissues of $1.00 \mathrm{mg} / \mathrm{kg}$ in 9 of $11 \mathrm{pal}-$ lid sturgeon tissues sampled. The greatest concentrations of mercury and selenium were found in pallid sturgeons collected near the mouth of the Yellowstone River. Excessive selenium in the ovaries of other fish species have been determined to adversely affect fish reproduction, mortality, and populations at concentrations similar to that found in the liver of the Yellowstone River pallid sturgeon. Selenium naturally occurs in greater concentrations in glacial deposits and upper Cretaceous formations along the upper Missouri River. Other contaminants analyzed and not detected or at near-detection limits in pallid sturgeon tissues included: heptachlor, aldrin, delta BHC (hexachlorobenzene), mirex, and toxaphene.

A few contaminant studies indicate links between environmental contaminants and potential reproductive problems in other sturgeon species. A recent contaminant study of shovelnose sturgeon in a 100 -mile $(161-\mathrm{km})$ reach of the Platte River (a large tributary of the lower Missouri River) downstream from Columbus, Nebr., (Schwarz and others, 2006) provides a more recent and extensive evaluation of the 
pallid sturgeon's closest relative in a small part of the sturgeon range. Schwarz and others (2006) summed up chlordane concentration in shovelnose sturgeon in the lower Platte River as follows:

"Shovelnose sturgeon from the lower Platte

River had lower concentrations of total chlor-

dane (mean $=0.047+/-0.02$ ) than those previously

reported for the Missouri River below Gavins

Point Dam, NE (Allen and Wilson, 1991). Chlor-

dane residues in shovelnose sturgeon collected in

1988 increased along a downstream gradient from

0.14 microgram per gram $(\mu \mathrm{g} / \mathrm{g})$ near Blair, NE, to

$0.33 \mu \mathrm{g} / \mathrm{g}$ at Atchison, KS (Allen and Wilson, 1991).

These results in conjunction with results from this

study, indicate that chlordane residues in shovelnose

sturgeon have decreased since 1988. The Biomoni-

toring of Environmental Status and Trends (BEST)

program reported a general decline in chlordane

residues from fish sampled from the Mississippi

River basin in 1986 and 1995" (Schmitt, 2002).

Schwarz and others (2006) also detected DDT, delta BHC, endrine, mirex, lindane, toxaphene, and cis-nonachlor in less than 50 percent of eight carcass or nine ovary samples, but DDE, DDD, alpha and gamma chlordane, oxychlordane, heptachlor epoxide, trans-nonachlor, and PCBs were frequently detected. Two ovary samples exceeded FDA humanhealth action levels for concentrations of total PCBs or total chlordane in edible fish tissue [2.0 and $0.3 \mathrm{mg} / \mathrm{kg}$ respectively (U.S. Food and Drug Administration, 2010)]. Dieldrin, total DDT (the sum of p,p' and o,p' isomers of DDT, DDE, and DDD), and total chlordane exceeded protective guidelines for fish-eating wildlife, but did not exceed any known fish-toxicity thresholds. Total DDT consisted mainly of p,p'-DDE (the most stable and toxic DDT metabolite) and was detected in seven of eight carcasses sampled and all nine ovary samples. Concentrations of total DDT in carcass tissues did not exceed a $0.2 \mu \mathrm{g} / \mathrm{g}$ wet-weight total DDT guideline for the protection of fish-eating wildlife (Newell and others, 1987), but this guideline was exceeded in three ovary samples. Total chlordane residues exceeded a $0.1 \mathrm{mg} / \mathrm{kg}$ wet-weight guideline for the protection of predatory fish (Eisler, 1990) in one carcass sample and four ovary samples (Schwarz and others, 2006).

Schwarz and others (2006) summarize PCB contamination of shovelnose sturgeon in the lower Platte River as follows:

"Concentrations of total PCBs in shovelnose sturgeon tissues exceeded a number of toxicity thresholds for fish, and potential adverse effects to sturgeon in the lower Platte River warrant concern. PCBs in six carcasses were above the $0.11 \mu \mathrm{g} / \mathrm{g}$ wetweight guideline for fish-eating wildlife (Newell and others, 1987), and two ovary samples exceeded a $0.3 \mathrm{mg} / \mathrm{kg}$ wet-weight egg guideline for the protection of aquatic life (Eisler 1986)", and
"Although the shovelnose sturgeon with the greatest concentration of PCBs was older (13 years) than the average age of sturgeon collected for this study (9 years), sample size $(\mathrm{n}=7)$ precluded any significance in the correlation between age and $\mathrm{PCB}$ carcass residues. Older fish typically have greater tissue concentrations of PCBs (Ion and others, 1997; Lafontaine and others, 2002). Concentrations of PCBs in shovelnose sturgeon carcass samples were generally below published toxicity thresholds in the Environmental Residue-Effects Database (ERED) (Environmental Residue-Effects Database, 2004). Toxicity concentrations in ERED for whole body adult fish (six different species) ranged from $0.14 \mathrm{mg} / \mathrm{kg}$ wet weight lowest observed effects concentration (LOEC) for liver effects to a $170 \mathrm{mg} / \mathrm{kg}$ wet weight toxicity threshold for reduced egg hatchability by 83 percent (Environmental ResidueEffects Database, 2004)"

Part of the lower Platte River is listed as impaired by PCBs by the USEPA. Generally, concentrations of most organochlorine contaminants in shovelnose sturgeon were less than those reported from other sites known to be contaminated by organochlorine compounds, but similar to those collected in the Missouri River by Ruelle and Henry (1994). However, limited sample sizes in these studies prevent statistical comparisons.

Shovelnose sturgeon and their eggs collected from the lower Missouri River have a consumption advisory because of concerns relating to greater concentrations of $\mathrm{PCB}$ and chlordane (Missouri Department of Health and Senior Services, 2009). Illinois (Ill.) also has a sturgeon consumption advisory (PCBs) on the Mississippi River between Lock and Dam 22 and Cairo, Ill. Intersexual shovelnose sturgeon from the middle Mississippi River were determined to have greater concentrations of organochlorine compounds than male shovelnose sturgeon (Koch and others, 2006). Lower Missouri River shovelnose sturgeons also have been noted to exhibit intersexual characteristics (Wildhaber and others, 2005). Research involving white sturgeon (Acipenser transmontanus) in the Columbia River indicated lower condition factors, gonadal abnormalities, and hermaphrodism in fishes with elevated levels of metabolites of DDT (DDE and DDD), as well as total PCBs and mercury (Fiest and others, 2005). The presence and effects of contaminants also are critical factors for egg survival and yolk reserves of hatchlings.

In addition to the lack of information on the effects of individual contaminants on pallid sturgeon health and reproduction, even less data exist on the cumulative effects of multiple contaminants on pallid sturgeon or other Missouri River fish. However, contaminant cocktails extracted from semi-permeable membrane devices (SPMDs) deployed in the Missouri River for 28 days were injected into rainbow trout and induced vitagellin production in male trout, indicating an estrogenic effect (Petty and others, 1998). 
Although the amount of data collected by Ruelle and Keenlyne (1993) from three pallid sturgeons sampled more than 20 years ago, all upstream from southeastern Nebraska, is small and dated, several contaminants were found in great enough concentrations to indicate contaminants can be affecting pallid sturgeon reproduction in the Missouri River. These minimal data on tissue concentrations of bioaccumulating contaminants in pallid sturgeon and more abundant contaminant analyses on shovelnose sturgeon in the Missouri River Basin indicate bioaccumulative compounds could be a cause of reproductive problems in pallid sturgeon. However, there are not enough data on pallid sturgeon to confirm or quantify this potential hazard. Not only are studies needed to determine what concentrations might impede pallid sturgeon recruitment, but sampling stocked pallid sturgeon tissues annually would help determine time trends in tissue concentrations, as many of the bioaccumulating contaminants are no longer used. Dead wild pallid sturgeon could be analyzed for these compounds. The U.S. Fish and Wildlife Service (2006) also concluded that research on the effects of contaminants on pallid sturgeon reproductive mechanisms should continue as part of pallid sturgeon recovery efforts. Subjecting hatchery-raised pallid sturgeon to SPMD extracts from the Missouri River could help quantify the effects of multiple bioaccumulating compounds.

Most bioaccumulative contaminants are attached primarily to fine sediments in water and, therefore, likely correlate with suspended-sediment concentrations or turbidity, or both. Therefore, regressions of bioaccumulative compounds with turbidity likely are to be significant and could be used to make continuous estimates of these contaminant concentrations in water to better assess exposure of pallid sturgeon and other fish to these compounds (Rasmussen and others, 2008). In addition, analysis of water samples routinely collected in existing sampling programs is needed for bioaccumulating compounds that have been documented to limit recruitment of pallid sturgeon and other related fish species.

\section{Atrazine, Pharmaceuticals, and Hormones}

Atrazine is hydrophilic and concentrations in fish blood generally follow concentrations in water (Schwarz and others, 2006). Adverse effects to fish occur at concentrations between 0.5 and 12 micrograms per liter $(\mu \mathrm{g} / \mathrm{L})$ (Schwarz and others, 2006). For example:

- The Nebraska chronic aquatic life standard is $12 \mu \mathrm{g} / \mathrm{L}$.

- Atrazine toxicity to some plants occurs at $10 \mu \mathrm{g} / \mathrm{L}$ (U.S. Environmental Protection Agency, 2003).

- Decreased temperature tolerance in some fish occurs at $10 \mu \mathrm{g} / \mathrm{L}$ (Messaad and others, 2000).

- Kidney damage in some fish species occurs at 5 to $10 \mu \mathrm{g} / \mathrm{L}$ (Fisher-Scheri and others, 1991).

- Deoxyribonucleic acid (DNA) strand breaks occur in some fish species at $7 \mu \mathrm{g} / \mathrm{L}$ (Chang and others, 2005).
- Altered fish behavior occurs at concentrations as low as $5 \mu \mathrm{g} / \mathrm{L}$ (Saglio and Trijasse, 1998).

- Endocrine effects occur in some fish at concentrations less than $3 \mu \mathrm{g} / \mathrm{L}$ (Moore and Lower, 2001).

- Egg production is decreased in fathead minnows (Pimephales promelas) at atrazine concentrations as low as $0.5 \mu \mathrm{g} / \mathrm{L}$, primarily because of decreased numbers of spawning events. Atrazine also decreased egg production through alteration of the final maturation of ooctes (Tillitt and others, 2010). Fathead minnows can be an important prey species of pallid sturgeon (Gerrity and others, 2006).

The median, maximum, and 75 th percentiles of mean May atrazine concentrations in samples collected at Omaha, Nebr., and Hermann, Mo. from 1991 through 2006 are shown in table 3 and indicate greater concentrations at the downstream site. Comparison of these data with the critical concentrations determined for non-sturgeon fish species listed above indicate that during at least part of the spawning season, atrazine concentrations are frequently large enough to have potential effects on pallid sturgeon.

Small concentrations of some hormones, pharmaceuticals, and organic wastewater compounds have been documented to have profound effects on the reproductive processes of fish including fathead minnows (a sturgeon prey species) (Vajda and others, 2008; Barber and others, 2007; and Folmar and others, 2001). The concentrations, geographic extent, and seasonal patterns of these compounds in the lower Missouri River are unknown as are the effects of environmental concentrations of hormones, pharmaceuticals, and organic wastewater compounds on pallid or shovelnose sturgeon.

Present (2011) concentrations of atrazine in the lower Missouri River indicate that toxicological studies of the effects of atrazine on the reproduction and recruitment of pallid sturgeon are warranted. Presently (2011), the number of water samples for hormones, pharmaceuticals, and wastewater compounds collected from the lower Missouri River is small or nonexistent. Therefore, the exposure of pallid sturgeon to these compounds in water and suspended sediments of the Missouri River needs to be characterized. If this exposure is hazardous to common fish species, then toxicological studies of these compounds on reproduction and recruitment of pallid sturgeon are warranted. Many of these compounds could be added as analytes of samples collected in ongoing long-term monitoring of the lower Missouri River by federal agencies or shorter term sampling by other institutions to assess and quantify the exposure of fish, including pallid sturgeon. Some of these compounds also could be analyzed from extracts of SPMDs that integrate concentrations over the period of time they are deployed. Exposure of Missouri River sturgeon to extracts from SPMDs would provide valuable information on the cumulative effects of multiple contaminants. 
Table 3. Median, maximum, and 75th percentile of mean-monthly atrazine concentrations in samples collected in May from 1991 through 2006 in the lower Missouri River.

[Computed from data available from the U.S. Geological Survey National Water Information System at http://nwis.waterdata.usgs.gov/ mo/nwis/dv/?referred_module $=q w$ ]

\begin{tabular}{lccc}
\hline Station location & $\begin{array}{c}\text { Median of mean May' } \\
\text { concentrations, } \\
\text { in micrograms per liter }\end{array}$ & $\begin{array}{c}\text { Maximum of mean May' } \\
\text { concentrations, } \\
\text { in micrograms per liter }\end{array}$ & $\begin{array}{c}\text { 75th percentile of mean May' } \\
\text { concentrations, } \\
\text { in micrograms per liter }\end{array}$ \\
\hline Omaha, Nebraska & 1.9 & 3.4 & 2.3 \\
Hermann, Missouri & 3.0 & 6.7 & 4.6 \\
\hline
\end{tabular}

${ }^{1}$ In most years, two or three samples were collected in May. The atrazine concentrations in these samples were averaged to compute a mean May concentration for each year.

\section{Summary and Conclusions}

Currently (2011), the pallid sturgeon has been listed by the U.S. Fish and Wildlife Service as an endangered species. The paucity of larval pallid sturgeon captures and the limited number of young wild pallid sturgeon in the lower Missouri River indicate sporadic or limited natural recruitment may be a primary contributor to the decline of pallid sturgeon. Water quality has been hypothesized to be a potential cause or contributor to the lack of pallid sturgeon recruitment in the lower Missouri River. Water quality encompasses a wide range of characteristics that may be associated with potential recruitment bottlenecks. These include habitat characteristics (such as water temperature, dissolved oxygen, and light), food-web constituents (such as nutrients, plankton, light, and organic material), and toxic contaminants (such as bioaccumulative compounds, hormones, and endocrine disruptors).

Pallid sturgeons likely have evolved to higher water temperatures than other sturgeon species. However, continuous temperature measurements on the lower Missouri River indicate that the water temperature often may be in the stressful range for juvenile pallid sturgeon during hot summers. Recent data on juvenile pallid sturgeon from a small study (18 fish) indicate that $28^{\circ} \mathrm{C}$ is the optimal temperature for feeding and growth, that temperatures from 30 to $33^{\circ} \mathrm{C}$ are stressful, and lethality begins at temperatures greater than $33^{\circ} \mathrm{C}$. The egg and larval stages are likely even more sensitive to high temperatures. Although adult pallid sturgeon might be able to find temperature relief by remaining in the northern end of the lower Missouri or perhaps find some local temperature refuge, drifting larvae have no ability to escape these higher temperatures, which could limit recruitment in abnormally hot summers. Temperature constraints could be expected to get worse if summer air temperatures in the Missouri River Basin increase in the coming decades as global climate models predict. Therefore, more comprehensive studies on the temperature preferences and tolerances of pallid sturgeon at younger life stages are needed to determine whether ambient water temperatures can limit the recruitment of pallid sturgeon in the Missouri River now (2011) or in the future.
Although instantaneous measurements of water temperature are available from numerous sources and for many decades, only continuous measurements can provide daily mean, maximum, and minimum temperatures. Because water temperature likely is an important trigger for sturgeon migration and spawning, peak summer water temperatures in the lower river may be stressful for pallid sturgeon, and the current period of continuous record is short; continuous water-temperature monitoring from March through September is needed at enough stations to provide a longitudinal resolution of $1.0^{\circ} \mathrm{C}$ or less. When temperatures are near $32^{\circ} \mathrm{C}$, even a $0.5^{\circ} \mathrm{C}$ temperature change may be important for pallid sturgeon survival.

Although the specific conductance and dissolved solids content of the lower Missouri River is greater than that in many rivers, pallid sturgeon appear to have a tolerance of much greater salinities. They have been collected from brackish water in the lower Mississippi River and near the mouth of the Atchafalaya River in Louisiana.

Pallid sturgeons generally prefer turbid water. Order-ofmagnitude decreases in the turbidity of the lower Missouri River that occurred after closure of several large upstream reservoirs may be a factor in decreased recruitment of pallid sturgeon. Post-impoundment turbidities may not provide young pallid sturgeon with adequate protection from predation, decrease numbers of native prey species, or increase the difficulty of capturing prey. Field studies and more comprehensive laboratory experiments on the effects of decreased turbidity on spawning behavior and the susceptibility of pallid sturgeon to piscivory, especially at the egg and larval stages, are needed to assess the effects of this fundamental change in the habitat of the pallid sturgeon. Also, field studies on the preference of spawning, larval, and early juvenile pallid sturgeon for higher-turbidity regions of the lower Missouri River, its side channels, and tributaries could shed light on the importance of turbidity to recruitment. Because turbidity varies 2 or 3 orders of magnitude with discharge, continuous turbidity monitoring is necessary to characterize the range of conditions and observe pallid-sturgeon response to shortterm changes in turbidity, relate field conditions to results of 
laboratory experiments, and help quantify productivity in the lower Missouri River.

No studies have been done on the tolerances of pallid sturgeon to oxygen depletion, although studies on other species of sturgeon, not in the Missouri River, suggest potential susceptibility to dissolved-oxygen concentrations less than $3 \mathrm{mg} / \mathrm{L}$. Observed concentrations of dissolved oxygen of less than $2 \mathrm{mg} / \mathrm{L}$ during spring and summer rises indicate a potential hazard to pallid sturgeon, especially at egg and larval life stages. Laboratory studies on the tolerance of pallid sturgeon to hypoxic conditions at all life stages are needed as well as field studies of potential methods pallid sturgeon may use to escape from hypoxic events. Real-time, continuous, dissolvedoxygen monitoring on the lower Missouri River would be useful to identify hypoxic conditions while tagged pallid sturgeon are tracked to determine where they go during periods of low-oxygen stress.

The post-impoundment lower Missouri River often is hypereutrophic because of increased clarity and nonlimiting nutrient concentrations. Recent zooplankton studies indicate large alterations of the zooplankton composition also resulting from impoundment of the Missouri River. Generally, river alterations likely have changed plankton in the lower Missouri River from a heterotrophic to a more autotrophic community. However, little data are available on temporal and spatial variation of the numerous species of phytoplankton, zooplankton, and other plankton in the lower Missouri River. Initiation of regular, systematic, and habitat-specific sampling of plankton is needed to characterize the structure and variability of the base of the lower Missouri River food web. Studies also are needed to assess how these compositional changes may have affected first-feeding larval pallid sturgeon. Continuous turbidity and oxygen monitoring is needed to help characterize the post-impoundment modern habitat of the pallid sturgeon, phytoplankton, and zooplankton in the lower Missouri River.

Although the amount of data collected from three pallid sturgeon sampled more than 20 years ago, all collected upstream from southeastern Nebraska, is small and dated, several contaminants (including polychlorinated biphenyls, chlordane, dichlorodiphenyltrichloroethane (DDT) and its metabolites, and mercury) that are particularly damaging to long-lived fish were found in great enough concentrations to indicate bioaccumulating contaminants can be affecting pallid sturgeon reproduction in the Missouri River. However, there are not enough data on pallid sturgeon to confirm or quantify this potential hazard. Not only are studies needed to determine what concentrations might impede pallid sturgeon recruitment, but sampling of stocked pallid sturgeon tissues annually would help determine time trends in tissue concentrations, as many of the bioaccumulating contaminants are no longer used. Dead wild pallid sturgeon also could be analyzed for these compounds. The U.S. Fish and Wildlife Service also concluded that research on the effects of contaminants on pallid sturgeon reproductive mechanisms should continue as part of pallid sturgeon recovery efforts. Hatchery-raised pallid sturgeon could be subjected to SPMD extracts from the Missouri River to quantify synergistic effects of multiple bioaccumulating compounds.

Most bioaccumulative contaminants primarily are attached to fine sediments in water and, therefore, likely correlate with suspended-sediment concentrations and turbidity. Therefore, regressions of bioaccumulative compounds with turbidity are likely to be significant and could be used to make continuous estimates of these contaminant concentrations in water to better assess exposure of pallid sturgeon and other fish to these compounds. In addition, analysis of water samples routinely collected in existing sampling programs is needed for bioaccumulating compounds that have been documented to potentially limit recruitment for pallid sturgeon and other related fish species.

Present (2011) concentrations of atrazine in the lower Missouri River indicate toxicological studies of the effects of atrazine on the reproduction and recruitment of pallid sturgeon are warranted. Presently (2011), the number of water samples analyzed for hormones, pharmaceuticals, and wastewater compounds collected from the lower Missouri River is small or nonexistent. Therefore, the exposure of pallid sturgeon to these compounds in water and suspended sediments of the Missouri River needs to be characterized. If this exposure is hazardous to common fish species, then toxicological studies of these compounds on reproduction and recruitment of pallid sturgeon are warranted. Many of these compounds could be added as analytes of samples collected in ongoing long-term monitoring of the lower Missouri River by federal agencies or shorter term monitoring by other government agencies to assess and quantify the exposure of fish, including pallid sturgeon. Some of these compounds also could be analyzed from extracts of SPMDs that integrate concentrations over the period of time they are deployed. Exposure of Missouri River sturgeon to extracts from SPMDs would provide valuable information on the cumulative effects of multiple contaminants.

\section{References Cited}

Allen, G.T., and Wilson, M.R., 1991, Metals and organic compounds in Missouri River fish in 1988: Contaminant Report Number R6/503M/91, U.S. Fish and Wildlife Service, Manhattan, Kansas, 69 p.

Barada, A.J., and Steffensen, K.D., 2006, 2005 Annual report, pallid sturgeon population assessment project and associated fish community monitoring for the Missouri River: Segment 8, Nebraska Game and Parks Commission., Lincoln, Nebraska.

Barber, L.B., Lee, K.E., Swackhamer, D.L., and Schoenfuss, H.L., 2007, Reproductive responses of male fathead minnows exposed to wastewater treatment plant effluent, effluent treated with XAD8 resin, and an environmentally relevant mixture of alkylphenol compounds: Aquatic Toxicology, v. 82, no. 1, p. 36-46. 
Berner, L.M., 1951, Limnology of the lower Missouri River: Ecology, v. 32, no. 1, p. 1-12.

Blevins, D.W., 2006, The response of suspended sediment, turbidity, and velocity to historical alterations of the Missouri River: U.S. Geological Survey Circular 1301, 8 p.

Blevins, D.W., Bartholomay, R., Neitzert, K., Rus, D., Wilson, R., Andersen, M., Kopish, R., and Haschemeyer, R., 2007, Water Quality and Hydrology, in Korschgen, C.E., ed., Factors affecting the reproduction, recruitment, habitat, and population dynamics of pallid sturgeon and shovelnose sturgeon in the Missouri River: U.S. Geological Survey, Open-File Report 2007-1262, p. 255-279.

Bowie, J.E., 1971, Temperature of Missouri streams: U.S. Geological Survey, 350 p.

Braaten, P.J., Fuller D.B., and McClenning, N.D., 2007, Diet composition of larval and young-of-year shovelnose sturgeon in the upper Missouri River: Journal of Ichthyology, v. 23 , p. 516-520.

Braaten, P.J., Fuller, D.B., Holte, L.D., Lott, R.D., Viste, W., Brandt, T.F., and Legare, R.G., 2008, Drift Dynamics of larval pallid sturgeon and shovelnose sturgeon in a natural side channel of the upper Missouri River, Montana: North American Journal of Fisheries Management, v. 28, p. 808-826.

Bramlett, R.G., and White, R.G., 2001, Habitat use and movement of pallid and Shovelnose sturgeon in the Yellowstone and Missouri rivers in Montana and North Dakota: Transactions of the American Fisheries Society, v. 130 , p. 1,006-1,025.

Campton, D.E., Bass, A., Chapman, F., and Bowen, B., 2000, Genetic distinction of pallid, shovelnose, and Alabama sturgeon-Emerging species and the Endangered Species Act: Conservation Genetics, v. 1, p. 17-32.

Carlson, D.M., Pflieger, W.L., Trail, L., and Haverland, P.S., 1985, Distribution, biology, and hybridization of Scaphirhynchus albus and S. platorynchus in the Missouri and Mississippi Rivers: Environmental Biology of Fishes, v. 14, p. 51-59.

Cech, J.J., Jr, and Doroshov, S.I., 2004, Environmental requirements, preferences and tolerance limits of North American sturgeons, Chap. 3 in LeBreton, G.T.O., Beamish, F.W.H., McKinley, R.S., eds., sturgeons and Paddlefish of North America: Kluwer Academic Publishers, Netherlands, p. 73-86.
Chang, L.W., Toth, G.P., Gordon, D.A., Graham, D.W., Meier, J.R., Knapp, C.W., DeNoyelles, J.F., Campbell, S., and Lattier, D.L., 2005, Responses of molecular indicators of exposure in mesocosms - Common carp (Cyprinus carpio) exposed to the herbicides alachlor and atrazine: Environmental Toxicology and Chemistry, v. 24, no. 1, p. 190-197.

Chapman, F.A., and Carr, S.H., 1995, Implications of early life stages in the natural history of the Gulf of Mexico sturgeon, Acipenser oxyinchus desotoi: Environmental Biology of Fishes, v. 43, p. 407-413.

Chipps, S.R., Klumb, R.A., and Wright, E.B., 2010, Development and application of juvenile pallid sturgeon bioenergetics model: Final Report, South Dakota State Wildlife Grant Program, Brookings, South Dakota, Study T-24-R Study No. 2424, 40 p.

Cowell, B.C., 1967, The copepoda and caldocera of a Missouri River reservoir - A comparison of sampling in the reservoir and the discharge: Limnology and Oceanography, v. 12, p. 125-136.

Crocker, C.E., and Cech, J.J., Jr., 1996, The effects of hypercapnia on the growth of juvenile white sturgeon, Acipenser transmontanus: Aquaculture, v. 147, p. 293-299.

Cross, F.B., 1967, Handbook of fishes of Kansas: Miscellaneous Publications of the Museum of Natural History, University of Kansas no. 45, p. 1-357.

Dettlaff, T.A., Ginsburg, A.S., Schmalhausen, O.I., 1993, Sturgeon fishes-Developmental biology and aquaculture: Berlin, Springer-Verlag, 300 p.

Dickerson, K.D., Medley, K.A., and Havel, J.E., 2010, Spatial variation in zooplankton community structure is related to hydrologic flow units in the Missouri River, USA: River Research and Applications, v. 26, no. 5, p. 605-18.

Echols, K.R., Brumbaugh, W.G., Orazio, C.E., May, T.W., Poulton, B.C., and Peterman, P.H., 2008, Distribution of PAHs, PCHs and bioavailable metals in depositional sediments of the lower Missouri River, USA: Archives of Environmental Contamination and Toxicology, v. 55, no. 2, p. 161-172.

Eisler, R., 1986, Polychlorinated biphenyl hazards to fish, wildlife, and invertebrates-A synoptic review: U.S. Fish Wild Service Biological Report 85(1.7), 53 p. (Also available at http://www.pwrc.usgs.gov/infobase/eisler/reviews. cfm.) 
Eisler, R., 1990, Chlordane hazards to fish, wildlife, and invertebrates - A synoptic review: U.S. Fish and Wild Service Biological Report 85(1.21), 49 p., http://www.pwrc. usgs.gov/infobase/eisler/reviews.cfm.

Ellis, M.M., 1937, Detection and measurement of stream pollution: Bulletin of the Bureau of Fisheries, v. 48, p. $365-437$.

Environmental Residue-Effects Database (ERED), 2004, U.S. Army Corps of Engineers, Waterways Experimental Station, Vicksburg, Miss., http://el.erdc.usace.army.mil/ered/.

Erickson, J.D., 1992, Habitat selection and movement of pallid sturgeon in Lake Sharpe, South Dakota: M.S. thesis, South Dakota State University, $70 \mathrm{p}$.

Ernst, W., 1984, Pesticides and technical organic chemicals: in Kinne, O., ed., Marine Ecology, John Wiley, New York, v. 4 , p. $1,617-1,709$.

Feist, G.W., Webb, M.A.H., Gundersen, D.T., Foster, E.P., Shreck, C.B., Maule, A.G., and Fitzpatrick, M.S., 2005, Evidence of detrimental effects of environmental contaminants on growth and reproductive physiology of white sturgeon in impounded areas of the Columbia River: Environmental Health Perspectives, v. 113, no. 12, p. 1,675-1,82.

Fisher-Scheri, T., Veeser, A., Hoffmann, R.W., Kühnhauser, C., Negele, R.D., and Ewringmann, T., 1991, Morphological effects of acute and chronic atrazine exposure in rainbow trout (Oncorhynchus mykiss): Environmental Contamination and Toxicology, v. 20, p. 454-461.

Folmar, L.C., Denslow, N.D., Kroll, K., Orlando, E.F., Enblom, J., Marcino, J., Metcalfe, C., and Guillette, L.J., Jr., 2001, Altered serum sex steroids and vitellogenin induction in walleye (Stizostedion vitreum) collected near a metropolitan sewage treatment plant: Archives of Environmental Contamination and Toxicology, v. 40, no. 3, p. 392-398.

Forbes, S.A., and Richardson, R.E., 1905, On a new shovelnose sturgeon from the Mississippi River: Bulliten Illinois State Laboratory of Natural History, v. 7, p. 37-44.

French, W.E., 2010, Predation, vulnerability, and trophic interactions of pallid sturgeon Scaphirhynchus albus: M.S. thesis, South Dakota State University, 59 p.

Gerrity, P.C., Guy, C.S., and Gardner, W.M., 2006, Juvenile pallid sturgeon are piscivores-A call for conserving native cyprinids: Transactions of the American Fisheries Society, v. 135 , p. 604-609.

Grohs, K.L., Klumb, R.A., Chipps, S.R., and Wanner, G.A., 2009 , Ontogenetic patterns in prey use by pallid sturgeon in the Missouri River, South Dakota and Nebraska: Journal of Applied Ichthyology, v. 25, (Suppl. 2), p. 48-53.
Haring, H.J., Blocksom, K.A., Smith, M.E., Angradi, T.R., Wratschko, M.C., Armstrong, B., Bolgrien, D., and Lazorchak, J.M., 2011, Sediment toxicity in mid-continent great rivers (USA): Archives of Environmental Contamination and Toxicology, v. 60, p. 57-67.

Havel, J.E., Medley, K.A., Dickerson, K.D., Angradi, T.R., Bolgren, D.W., Bukaveckas, P.A., and Jicha, T.M., 2009, Effect of main-stem dams on zooplankton communities of the Missouri River (USA): Hydrobiologia, v. 628, p. 121-135.

Hesse, L.W., 1987, Taming the wild Missouri River-What has it cost?: Fisheries, v. 12, no. 2, p. 2-9.

Hesse, L.W., and Mestl, G.E., 1988, Paddlefish predicament: Nebraskaland (July), p. 23-25 and p. 44-46.

Intergovernmental Panel on Climate Change, 2007, Climate Change 2007-The physical science basis: Contribution of Working Group I to the Fourth Assessment Report of the Intergovernmental Panel on Climate Change, Cambridge University Press, Cambridge, United Kingdom and New York, N.Y., USA, 996 p.

Ion, J., Lafontaine, Y.D., Dumont, P., and Lapierre, L., 1997, Contaminant levels in St. Lawrence River yellow perch (Perca flavescens) - Spatial variation and implications for monitoring: Canadian Journal of Fisheries and Aquatic Sciences, v. 54, no. 12, p. 2,930-2,946.

Jenkins, W.E., Smith, T., Heyward, L., and Knott, D.M., 1993, Tolerance of shortnose sturgeon, Acipnser brevirostrum, juveniles to different salinity and dissolved oxygen concentrations: Proceedings of the annual conference / Southeastern Association of Fish and Wildlife Agencies, v. 47, p. 476-484.

Jennings, D.K., 1979, An evaluation of aquatic habitat associated with notched dikes on the Missouri River, Missouri: M.S. thesis, University of Missouri-Columbia, 262 p.

Jobling, M., 1995, Environmental biology of fishes: London, Chapman and Hall, 455 p.

Kallemeyn, L.W., and Novotny, J.F., 1977, Fish and fish food organisms in various habitats of the Missouri River in South Dakota, Nebraska, and Iowa: U.S. Fish and Wildlife Service, Office of Biological Services, National Stream Alteration Team, FWS/OBS-77/25, Columbia, Mo., USA.

Kapperman, K.M., Fraser, W.C., Toner, M., Dean, J., and Webb. M.A.H., 2009, Effect of temperature on growth, condition, and survival of juvenile shovelnose sturgeon. Transactions of the American Fisheries Society, v. 138, p. 927-937. 
Kasumyan, A.O., 2002, Sturgeon food searching behavior evoked by chemical stimuli-A reliable sensory mechanism: Journal of Applied Ichthyology, v. 18, p. 685-690.

Keenlyne, K.D., 1989, A report on the pallid sturgeon: U.S. Fish and Wildlife Service, Pierre, S. Dak., 20 p.

Kelly, B.P., and Rydlund, P.H., Jr., 2006, Water-quality changes caused by riverbank filtration between the Missouri River and three pumping wells of the Independence, Missouri well field 2003-05: U.S. Geological Survey Scientific Investigations Report 2006-5174, 48 p.

Kennedy, A.J., Hormer, P.T., and Travenichek, V.H., 2006, 2005 Annual Report, Pallid sturgeon population assessment project and associated fish community monitoring for the Missouri River: Segment 10, Missouri Department of Conservation, Chillicothe, Mo.

Koch, B.T., Garvey, J.E., You, J., and Lydy, M.J., 2006, Elevated organochlorines in the brain-hyppothalamic-pitutary complex of intersexual shovelnose sturgeon: Environmental Toxicology and Chemistry, v. 25, no. 7, p. 1,689-1,697.

Kolar, C.S., Chapman, D.C., Courtenay, W.R., and Jennings, D.P., 2007, Big Headed Carps-A biological synopsis and environmental risk assessment: American Fisheries Society Special Publication 33, American Fisheries Society, Bethesda, Md., 204 p.

Lafontaine, Y.D., Gilbert N.L., Dumouchel, F., Brochu, C., Moore, S., Pelletier, E., Dumont, P., and Branchaud, A., 2002, Is chemical contamination responsible for the decline of the copper redhorse (Moxostoma hubbsi), an endangered fish species, in Canada?: Science of the Total Environment, v. 298 , no. $1-3$, p. $25-44$.

Mayden, R.L, Kuhajda, B.R., 1997, Threatened fishes of the world-Scaphirhynchus albus (Forbes \& Richardson, 1905) (Acipenseridae): Environmental Biology of Fishes, v. 48, p. 420-421.

Messaad, I.A., Peters, E.J., and Young, L., 2000, Thermal tolerance of Red Shiner (Cyprinella lutrenisis) after exposure to atrazine, terbufos, and their mixtures: Bulletin of Environmental Contamination and Toxicology, v. 64, p. 748-754.

Missouri Department of Health and Senior Services, 2009, 2009 Fish Advisory, a guide to eating fish in Missouri, accessed Sept. 12, 2011 at http://health.mo.gov/living/ environment/fishadvisory/index.php.

Moore, A., and Lower, N., 2001, The impact of two pesticides on olfactory-mediated endocrine function in mature male Atlantic salmon (Salmo salar L.) parr.: Comparative Biochemistry and Physiology, part B, v. 129, p. 269-276.
Morris, L.A., Langemeier, R.N., Russel, T.N., and Witt, A., 1968, Effects of main stem impoundments and channelization upon the limnology of the Missouri River, Nebraska: Transactions of the American Fisheries Society, v. 97, p. $380-388$.

Neel, J.K., 1963, Main stem reservoir effects on water quality in the central Missouri River 1952-1957: Public Health Service, Water Supply and Pollution Control Division, Kansas City, Mo., 112 p.

Newell, A.J., Johnson, D.W., and Allen L.K., 1987, Niagara River biota contamination project-fish flesh criteria for piscivorous wildlife: New York State Department of Environmental Conservation, Division of Fish and Wildlife, Bureau of Environmental Protection, Technical Report 87-3, 180 p.

Petty, J.D., Poulton, B.C., Charboneau, C.S., Huckins, J.N., Jones, S.B., Cameron, J.T., and Prest, H.F., 1998, Determination of bioavailable contaminants in the lower Missouri River following the flood of 1993: Environmental Science and Technology, v. 32, no. 7, p. 837-842.

Pfleiger, W.L., and Grace, T.B., 1987, Changes in the fish fauna of the lower Missouri River, 1940-1983, p. 166-177 in Matthews, W.J., and Heins, D.C., eds., Community and evolutionary ecology of North American stream fishes: University of Oklahoma Press, Norman, Okla.

Pillsbury, A.F., 1981, The salinity of rivers: Scientific American, v. 245, no. 1, p. 54-65.

Platner, W.S., 1946, Water quality studies of the Mississippi River: Fish and Wildlife Service Special Scientific Report 30, p. 1-77.

Poulton, B.C., Allert A.L., 2011, An evaluation of the quality of dike pools for benthic macroinvertebrates in the lower Missouri River, USA: River Research and Applications, 22 p. (Also available at http://onlinelibrary.wiley.com/ doi/10.1002/rra.1558/pdf).

Public Health Service, 1952, Lower Missouri River basin water pollution investigation: Federal Security Agency, Public Health Service Water Pollution Series No. 47, Publication no. 269, 187 p.

Quist, M.C., 2004, Research and assessment needs for pallid sturgeon recovery in the Missouri River: Proceedings of Conference held May 18-20, 2004, Report to the U.S. Geological Survey, U.S. Army Corps of Engineers, U.S. Fish and Wildlife Service, and U.S. Environmental Protection Agency. 82 p. 
Rasmussen, T.J., Lee, C.J., and Ziegler, A.C., 2008, Estimation of constituent concentrations, loads, and yields in streams of Johnson County, northeast Kansas, using continuous waterquality monitoring and regression models, October 2002 through December 2006: U.S. Geological Survey Scientific Investigations Report 2008-5014, 103 p.

Rostad, C.E., 1997, From the 1988 drought to the 1993 flood-Transport of halogenated organic compounds with the Mississippi River suspended sediment at Thebes, Illinois: Environmental Science and Technology, v. 31, p. $1,308-1,312$.

Ruelle, R., and Henry, C., 1994, Life history observations and contaminant evaluation of pallid sturgeon, final report: U.S. Fish and Wildlife Service, South Dakota Field Office, 33 p.

Ruelle, R., and Keenlyne, K.D., 1993, Contaminants in Missouri River pallid sturgeon: Bulletin of Environmental Contamination and Toxicology, v. 50, p. 898-906.

Ruelle, R., and Keenlyne, K.D., 1994, Contaminant information bulletin-The suitability of shovelnose sturgeon as a pallid surrogate: SD-ES-94-03, U.S. Fish and Wildlife Service, Pierre, S. Dak.

Russel, T.R., 1986, Biology and life history of paddlefish-A review in Dillard, J.D., Graham, L.K., and Russel, T.R., eds.: Paddlefish-Status, management and propagation: N. Central Division American Fisheries Society, Special Publication, no. 7, 159 p.

Saglio, P., and Trijasse, S., 1998, Behavioral responses to atrazine and diuron in goldfish: Archives of Environmental Contamination and Toxicology, v. 35, no. 3, p. 484-491.

Schmitt, C.J., 2002, Biomonitoring of Environmental Status and Trends (BEST) Program-Environmental contaminants and their effects on fish in the Mississippi River Basin: U.S. Geological Survey, Biological Science Report 2002-0004, $241 \mathrm{p}$.

Schwarz, M.S., Lydick, C.D., Tillitt, D.E., Papoulias, D.M., and Gross, T.S., 2006, A health risk evaluation for pallid sturgeon (Scaphirhynchus albus) in the lower Platte River using shovelnose sturgeon (Scaphirhynchus platorynchus) as a surrogate: U.S. Fish and Wildlife Service, Division of Environmental Quality, Region 6, final Report, Grand Island, Nebr., 105 p.

Sillman, A.J., O'Leary, C.J., Tarantino, C.D., and Loew, E.R., 1999, The photoreceptors and visual pigments of two species of Acipenseriformes, the shovelnose sturgeon and the paddlefish: Journal of Comparative Physiology A, v. 184, p. 37-47.
Steffensen, K.D., and Barada, A.J., 2006, 2005 Annual report, pallid sturgeon population assessment project and associated fish community monitoring for the Missouri River: Segment 9, Nebraska Game and Parks Commission, Lincoln, Nebr.

Tillitt, D.E., Papoulias, D.M., Whyte, J.J., and Richter, C.A., 2010, Atrazine reduces reproduction in fathead minnow (Pimephales promelas): Aquatic Toxicology, v. 99, p. 149-159.

Tranah, G., Campton, D.E., and May, B., 2004, Genetic evidence of hybridization of pallid and shovelnose sturgeon: Journal of Heredity, v. 95, no. 6, p. 474-480.

Unkenholz, D.G., 1986, Effects of dams and other habitat alterations on paddlefish sport fisheries, in Dillard, J.G., Graham, L.K., and Russel, T.R., eds., Paddlefish-Status, management and propagation: N. Central Division American Fisheries Society, Special Publication, no. 7, 159 p.

U.S. Environmental Protection Agency, 1986, Ambient water quality criteria for dissolved oxygen: Criteria and Standards Division, U.S. Environmental Protection Agency, Washington, D.C., EPA-440/5-86-003.

U.S. Environmental Protection Agency, 2003, Ambient aquatic life water quality criteria for atrazine revised draft: EPA822-R-03-023, 178 p., accessed September 12, 2011, at http://www.epa.gov/waterscience/criteria/atrazine/rev-draft. $p d f$.

U.S. Fish and Wildlife Service, 1990, Endangered and threatened wildlife and plants - Determination of endangered status for the pallid sturgeon: Federal Register, v. 55, no. 173, p. $36,641-36,647$.

U.S. Fish and Wildlife Service, 2000, Biological opinion on the operation of the Missouri River mainstem reservoir system, operational maintenance of the Missouri River Bank Stabilization and Navigation Project, and operation of the Kansas Reservoir System: Region 6, Denver, Co., Region 3, Ft. Snelling, Minn., 325 p. (Also available at $h t t p: / / w w w$. nwd-mr.usace.army.mil/mmanual/opinion.html)

U.S. Fish and Wildlife Service, 2006, Pallid sturgeon (Scaphirhynchus albus) 5-year review summary and evaluation: $120 \mathrm{p}$.

U.S. Food and Drug Administration, 2010, Pesticide residues in food and feed-Enforcement: Compliance Policy Guide Section 575.10. (Also available at http://www.fda.gov/ICECI/ComplianceManuals/ CompliancePolicyGuidanceManual/ucm123236.htm) 
Utrup, N., Doyle, W., Lee, C., Plauck, A., and Hill, T., 2006, 2005 Annual report, pallid sturgeon population assessment project and associated fish community monitoring for the Missouri River: segment 14, U.S. Fish and Wildlife Service, Columbia, Mo.

Vajda, A.M., Barber, L.B., Gray, J.L., Lopez, E.M., Woodling, J.D., and Norris, D.O., 2008, Reproductive disruption in fish downstream from an estrogenic wastewater effluent: Environmental Science and Technology, v. 42, no. 9, p. $3,407-3,414$.

Vladykov, V.D., and Greeley, J.R., 1963, Order Acipenseroidei, p. 24-60, in Olsen, Y.H., ed., Fishes of the western North Atlantic, part 3: Sears Foundation for Marine Research, Yale University, New Haven, Conn.

Vodicnik, M.J., and Peterson, R.E., 1985, The enhancing effects of spawning on elimination of a persistent polychlorinated biphenyl from female yellow perch: Fundamental and Applied Toxicology, v. 5, p. 770-776.

Wang, Y.L., Binkowski, F.P., and Doroshov. S.I., 1985, Effect of temperature on early development of white and lake sturgeon, Acipenser trnasmountanus and A. fulvescens, p. 43-50 in Binkowski, F.P., and Doroshov, S.I., eds., North American sturgeons-Biology and aquaculture potential: Dr. W. Junk Publishers, Dordrecht, The Netherlands.

Wang, Y.L., Binkowski, F.P., and Doroshov, S.I., 1987, Influence of temperature on yolk utilization by the white sturgeon, Acipenser transmontonus: Journal of Fish Biology, v. 30 , p. $263-271$.
White, D.H., Mitchell, C.A., Kennedy, H.D., Krynitsky, A.J., and Ribick, M.A., 1983, Elevated DDE and toxaphene residues in fish and birds reflect local contamination in lower Rio Grande Valley, Texas: Southwestern Naturalist, v. 28, p. 325-333.

Whitley, J.R., and Campbell, R.S., 1974, Some aspects of water quality and biology of the Missouri River: Transactions of the Missouri Academy of Science, v. 7-8, p. 60-70.

Wildhaber, M.L., DeLonay, A.J., Papoulias, D.M., Galat, D.L., Jacobson, R.B., Simpkins, D.G., Braaten, P.J., Korschgen, C.E., and Mac, M.J., 2007, A conceptual life history model for pallid and shovelnose sturgeon: U.S. Geological Survey Circular 1315, 18 p.

Wildhaber, M.L., Papoulias, D.M., DeLonay, A.J., Tillet, D.E., Bryan, J.L. Annis, M.L., and Allert, J.A., 2005, Gender identification of shovelnose sturgeon using ultrasonic and endoscopic imagery and the application for the method in pallid sturgeon: Journal of Fish Biology, v. 67, p. 114-132.

Williams, L.G., 1966, Dominant planktonic rotifers of major waterways of the United States: Limnology and Oceanography, v. 11, no. 1, p. 83-91.

Williams, L.G., 1972, Plankton diatom species biomasses and the quality of American rivers and the Great Lakes: Ecology, v. 53, p. 1,038-1,050.

Publishing support provided by:

Rolla Publishing Service Center

For more information concerning this publication, contact:

Director

USGS Missouri Water Science Center

1400 Independence Road

Rolla, M0 65401

(573) 308-3667

Or visit the Missouri Water Science Center Web site at: http://mo.water.usgs.gov/ 


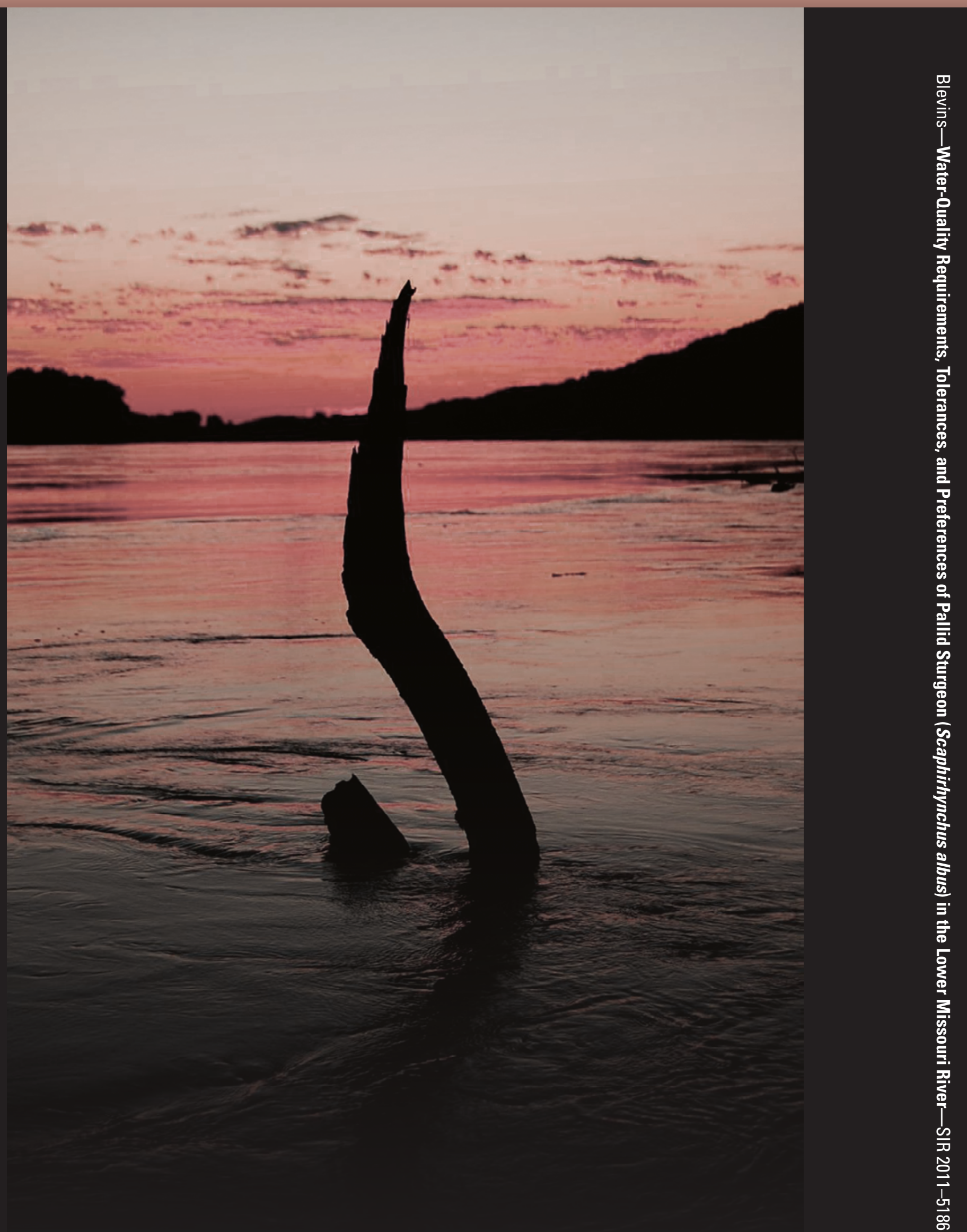